\title{
Factors Affecting Recruitment of Young Colorado Pikeminnow: Synthesis of Predation Experiments, Field Studies, and Individual-Based Modeling
}

\author{
K. R. Bestgen* and D. W. Beyers ${ }^{1}$ \\ Larval Fish Laboratory, Department of Fishery and Wildlife Biology, Colorado State University, \\ Fort Collins, Colorado 80523-1474, USA \\ J. A. RICE \\ Department of Zoology, North Carolina State University, Raleigh, North Carolina 27695-7617, USA
}

\author{
G. B. HAINES \\ U.S. Fish and Wildlife Service, Colorado River Fishery Project, \\ 1380 South 2350 West, Vernal, Utah 84078, USA
}

\begin{abstract}
Predation experiments, field studies, and individual-based-model (IBM) simulations revealed factors that affected the survival and recruitment of early life stages of endangered Colorado pikeminnow Ptychocheilus lucius in the Green River basin, Utah and Colorado. Small-bodied, nonnative red shiners Cyprinella lutrensis attacked Colorado pikeminnow larvae an average of once per minute, and predation success approached $30 \%$ in laboratory aquaria. Attack rate was also high in mesocosm experiments; turbidity and alternative prey reduced predation success. Distributions of hatching dates derived from otolith daily increment analysis showed that large cohorts of Colorado pikeminnow larvae that hatched in the Green River in early summer had low survival to autumn and that the few survivors were fast growing. Larvae hatched in midsummer or later had higher survival. Autumn juveniles grew 12-73\% faster than summer juveniles, which suggested differential mortality of slow-growing fish. The IBM simulations integrated size-dependent predator-prey relationships, Colorado pikeminnow life history information, temperature-dependent pikeminnow growth, Green River predator size-structure dynamics, seasonally variable Green River water temperatures, and turbidity and alternative prey availability effects; the simulations showed that red shiner predation interacting with environmental variables may significantly reduce age- 0 pikeminnow recruitment in autumn. Recruitment and growth patterns from simulations and field observations were consistent and suggested that the IBM is useful in evaluating management scenarios. Experiments, field studies, and predictive modeling provided consistent evidence that interacting effects of predation and environmental variables, including flow fluctuations, may structure intra-annual growth and recruitment patterns of age- 0 Colorado pikeminnow. Flow management to benefit growth and survival of young pikeminnow, particularly early hatching ones, and reduced nonnative predator abundance in Green River backwaters may enhance the Colorado pikeminnow populations.
\end{abstract}

Recruitment is central to the population ecology of fish because the abundance and survival rates of young in a cohort can have a strong influence on year-class strength in later life (Hjort 1914; Thorson 1950; Roughgarden et al. 1988). Factors that affect recruitment variation are of theoretical and practical interest (Hilborn and Walters 1992) and are often a focus of managers charged with resource conservation and recovery. Understanding the mechanisms that regulate recruitment is challenging because life history process-

\footnotetext{
* Corresponding author: kbestgen@cnr.colostate.edu

1 Present address: 330 Smythe Drive, Williams Bay, Wisconsin 53191, USA.
}

Received June 27, 2005; accepted March 28, 2006 Published online November 30, 2006 es such as the timing and success of reproduction, growth, and rates of survival and dispersal of young are influenced by biological and physical factors (Thorson 1950; Connell 1961; Roughgarden et al. 1985; Fogarty et al. 1991; Magnuson 1991). For example, fluctuations in physical characteristics of rivers (e.g., discharge, water temperature, and sediment transport regimes) can influence timing of reproduction and habitat availability, which in turn affect growth and survival of early life stages of fish (Welcomme 1979; Crecco and Savoy 1985; Limburg 1996; Mion et al. 1998). Biological processes such as predation, competition, and starvation can interact with physical factors and affect recruitment of young (May 1974; Hunter 1981; Houde 1987; Bailey and Houde 1989). Because the importance of physical and biological processes may shift 
within or among years, an understanding of recruitment variation at multiple temporal and spatial scales can help identify factors that regulate fish communities and focus conservation efforts for rare species (Hjort 1914; Methot 1983; Rice et al. 1987; Gaines et al. 1985; Connell 1985; Doherty 1991; Garvey et al. 2002).

The Colorado pikeminnow Ptychocheilus lucius is an endangered species (under the U.S. Endangered Species Act) endemic to the Colorado River basin in the American Southwest. Distribution and abundance of this large, piscivorous cyprinid have been reduced by human-induced changes to the physical and biological environment. Physical changes are largely due to construction and operation of dams, which restrict movement of Colorado pikeminnow; reduce seasonal discharge variability, water temperature, and sediment load; and increase daily hydrograph variation (Vanicek and Kramer 1969; Holden 1979; Tyus and Karp 1989; Tyus 1991; Stanford et al. 1996). Biological changes are mostly related to establishment of over 60 nonnative fishes, which may compete with or prey upon native fishes (Carlson and Muth 1989; Minckley and Deacon 1991). As a result, distribution and abundance of natural populations of Colorado pikeminnow have declined and are currently restricted to a few individuals in the San Juan River and more substantial populations in the upper Colorado River basin upstream of Lake Powell (Platania et al. 1991; Tyus 1991).

In upper Colorado River basin streams, the Green River population of Colorado pikeminnow is thought to be the largest, but recruitment of age- 0 fish in autumn varies annually (Tyus 1991; Tyus and Haines 1991; Osmundson and Burnham 1998; Bestgen et al. 2005). Recruitment variation may be due, in part, to intra-annual and interannual variation in abundance of nonnative cyprinids in backwaters, which may compete with or prey upon co-occuring early life stages of Colorado pikeminnow throughout their first summer and autumn of life (Tyus and Haines 1991; Tyus and Saunders 2000). Nonnative fishes include cyprinids $(<80 \mathrm{~mm}$ total length [TL]) such as red shiners Cyprinella lutrensis, fathead minnow Pimephales promelas, and sand shiners Notropis stramineus, which compose $90-99 \%$ of the fish community in backwaters (Haines and Tyus 1990; J. M. Bundy and K. R. Bestgen, unpublished report evaluating the interagency standardized monitoring program sampling technique in backwaters of the Colorado River). Although these small minnows have generally been overlooked as piscivores, predation by red shiners on cypriniform larvae has been documented (Ruppert et al. 1993; Brandenburg and Gido 1999). Red shiners have been widely introduced in many streams in the western $\mathrm{U}$. S., and given their high densities, even modest rates of predation may be an important source of mortality for early life stages of native fishes, including Colorado pikeminnow. Understanding sources of Colorado pikeminnow mortality during the first growing season merits particular attention because strong year-classes of juveniles (30-70-mm TL) are thought responsible for subsequent strong year-classes of adults in the Colorado and Green rivers (Osmundson and Burnham 1998; Bestgen et al. 2005).

The purpose of this investigation was to enhance understanding of factors that control the recruitment dynamics of young Colorado pikeminnow in their first summer of life. We first conducted small-scale experiments to evaluate effectiveness of nonnative red shiners as a predator on Colorado pikeminnow larvae. Red shiners were used because they are abundant, predaceous on cypriniform larvae (Ruppert et al. 1993), and their abundance can be affected by mechanical removal or high stream flows (Haines and Tyus 1990; Tyus and Saunders 2000). Second, we examined large-scale patterns of growth and recruitment of early life stages of wild Colorado pikeminnow in the Green River by analysis of daily increment patterns in otoliths (Pannella 1971; Campana and Neilson 1985; Bestgen and Bundy 1998; Bundy and Bestgen 2001). Intra-annual patterns of growth and survival of cohorts of larvae were then related to time of hatching and environmental events that may influence recruitment (Methot 1983; Crecco and Savoy 1985; Post and Prankevicius 1987; Rice et al. 1987; Limburg 1996; Mion et al. 1998; Garvey et al. 2002). Third, we developed an individual-based simulation model (IBM) that integrated results of experiments, field studies, and environmental variables and used it to explore potential mechanisms for growth and recruitment patterns observed in wild populations of age- 0 Colorado pikeminnow through their first summer. We also used IBM simulations to predict recruitment patterns of Colorado pikeminnow under hypothetical management actions (e.g., predator reductions, water temperature changes), and compared simulation predictions to patterns observed for wild populations to test model generality. Synthesis of these investigations allowed us to evaluate relative effects of various physical and biological factors on growth and survival of early life stages of Colorado pikeminnow.

\section{Colorado Pikeminnow Natural History}

The Colorado pikeminnow has a complex life history depicted in a conceptual model that links developmental stages with some important biotic and abiotic controlling factors (Figure 1; Bestgen et al. 1997). Large-bodied adult Colorado pikeminnow $(>450 \mathrm{~mm}$ TL) in the Green River basin of Colorado and Utah migrate to two spawning areas in spring 
Biotic Controlling Factors

Number and condition of adults Age and size structure of adults Timing of spawning

Predation on embryos and larvae

Physical disturbance of spawning site by other fish
Embryos and Larvae in substrate

\section{Abiotic Controlling Factors}

Timing and magnitude of runoff

Substrate characteristics, siltation, oxygen

Discharge fluctuations

Water temperature

Stochastic events (e.g., floods and pollutants)

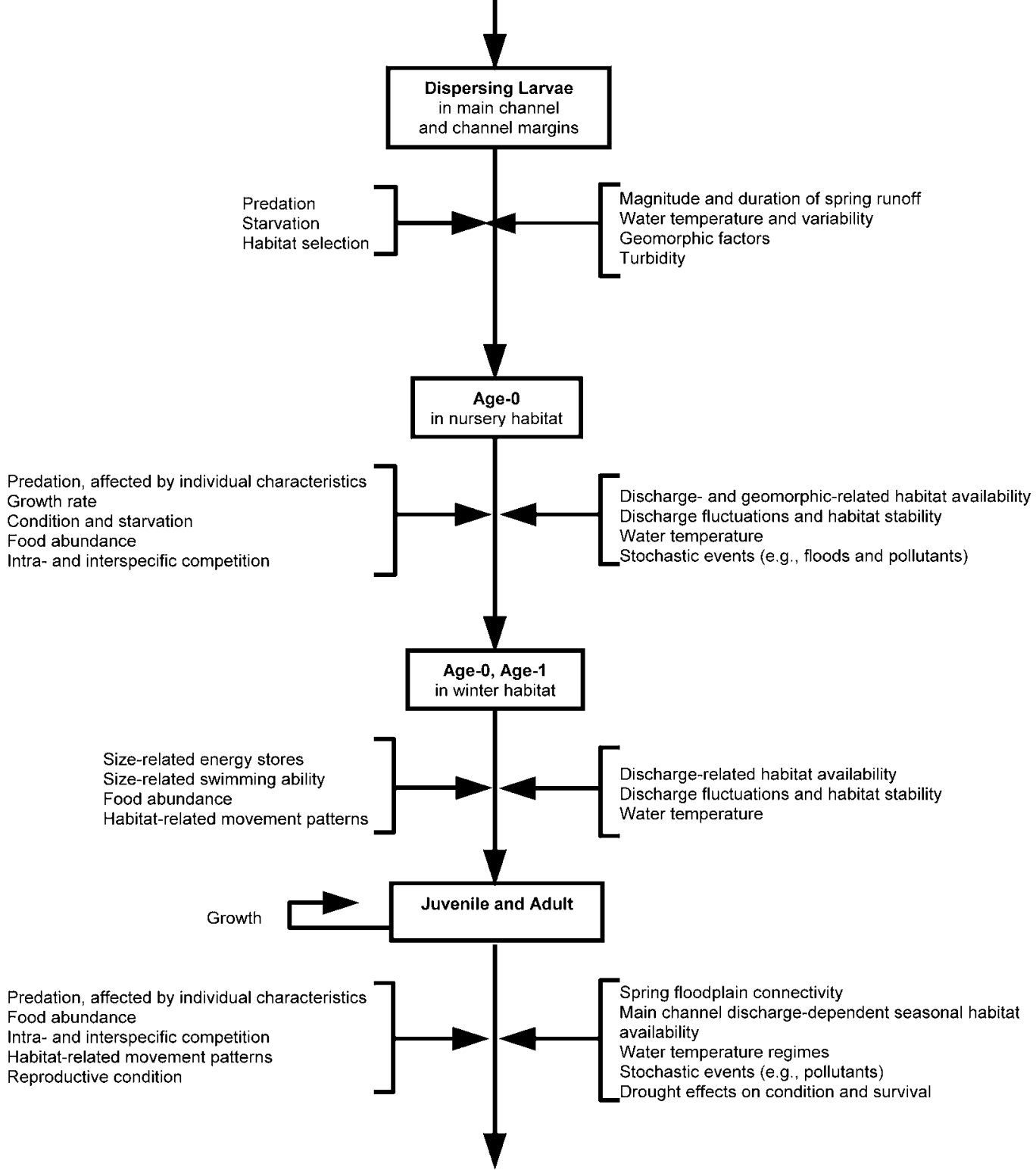

FIGURE 1.-Conceptual life history model of Colorado pikeminnow recruitment to various developmental stages and important biotic and abiotic factors that control them. 


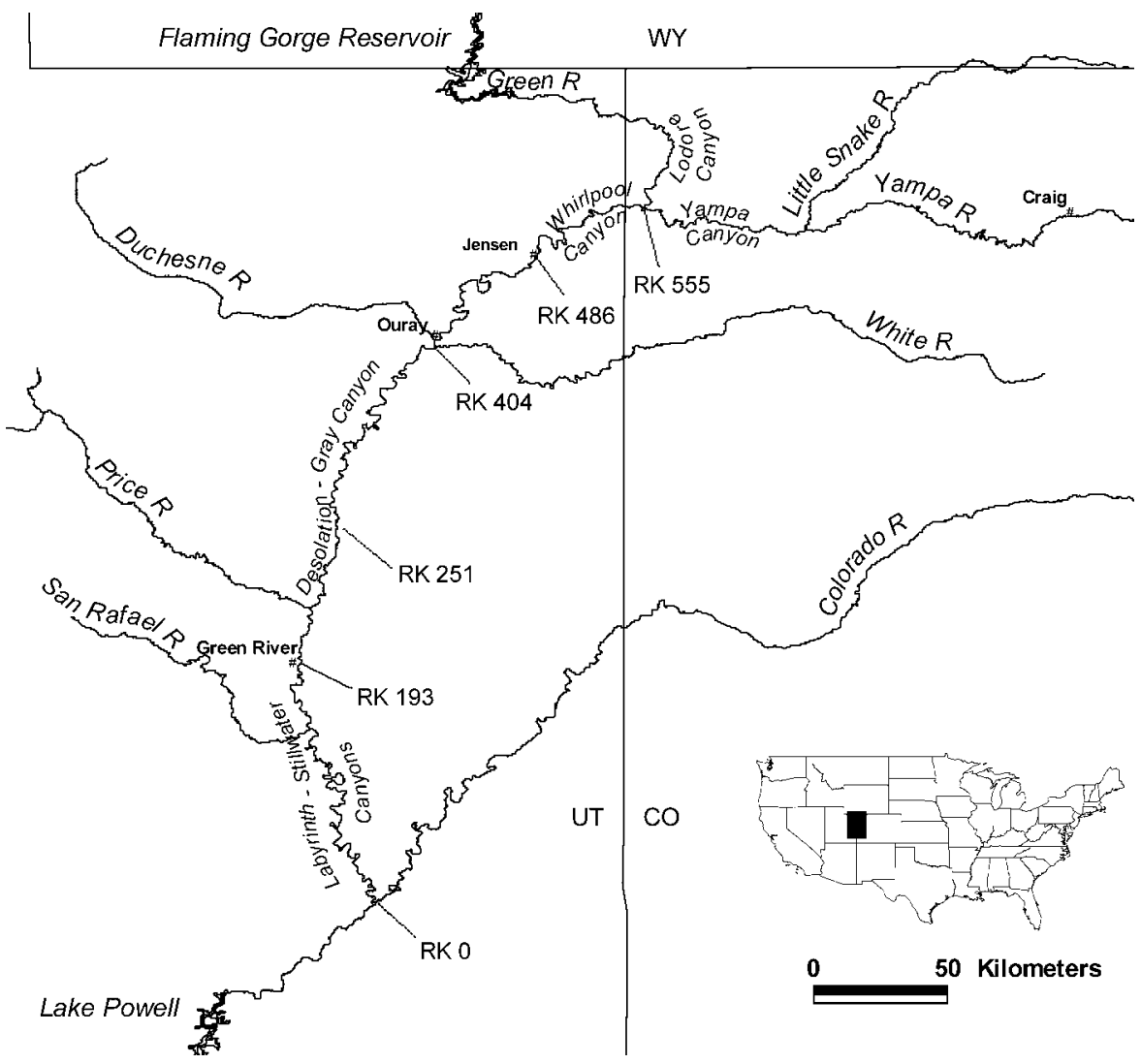

FIgure 2.- The Green River basin study area. Primary spawning areas are in Yampa Canyon and Gray Canyon downstream of river kilometer (RK) 251. Primary nursery habitat for age-0 pikeminnow was the middle (RKs 340-515) and lower (RKs 0-211, where RK 0 is at the Colorado River confluence) Green River. Circles indicate cities.

(Figure 2). Spawning begins 4-6 weeks after peak spring runoff, when water temperatures exceed 16$18^{\circ} \mathrm{C}$, and extends up to 6 weeks (Nesler et al. 1988; Tyus and Haines 1991; Bestgen et al. 1998). Embryos deposited over cobble bars develop in interstitial spaces for 4-6 d at temperatures of $18-26^{\circ} \mathrm{C}$ (Hamman 1981; Bestgen and Williams 1994). Emerging larvae, 7-9 $\mathrm{mm}$ TL, are transported by river currents $40-200 \mathrm{~km}$ or more downstream to low-gradient valley reaches, where they occupy shallow, low-velocity backwater nursery habitats (Bestgen and Williams 1994; Bestgen et al. 1998) for the duration of the growing season (Tyus and Haines 1991). Growth, survival, and recruitment of early life stages of Colorado pikeminnow in their first summer of life is the primary focus of this paper.

\section{Methods \\ Laboratory Experiments}

Experiments were conducted in aquaria and in mesocosms that simulated nursery habitat conditions, so that size-dependent predator-prey interactions and effects of turbidity, alternative prey, and predator behavior could be described. The likelihood of a fish larva being eaten by a predator is the product of at least three probabilities: the probability of being encountered by a predator, the probability of being attacked if encountered, and the probability of being captured if attacked (Gerritsen and Strickler 1977). We conducted experiments to determine red shiner probability of capture and encounter rates, so that the IBM could be constructed using data specific to the system and fishes of interest. We present findings of some experimental data in Methods to facilitate understanding and streamline presentation of laboratory and modeling results later.

Probability of capture.-Data that described the probability that a Colorado pikeminnow larva would be captured by a red shiner when an attack occurred were collected by observing the outcome of predation events in laboratory aquaria. A $6 \times 6$ factorial design was used. The first factor, predator size (mean TL), had six 
levels: 38, 47, 53, 61, 63, and $69 \mathrm{~mm}$. The second factor, prey size (mean TL), also had six levels: 9.8, $11.1,13.6,15.3,17.2$, and $18.7 \mathrm{~mm}$. We completed three trials for each size-class of prey per each sizegroup of predator (or $3 \times 36=108$ trials), plus 12 additional trials for the 11.1-mm prey size. In each trial, five pikeminnow larvae of the same size category were introduced into a 38-L glass aquarium containing three red shiners from one of the six different predator sizegroups; subsequent trials were completed such that each larval size was separately tested with each predator size. Each predator was watched by a separate observer, and the number of attacks and successful captures during two consecutive 10-min intervals were recorded. If three or more larvae were captured during a trial, an additional five larvae were added to the aquarium. Predators were assumed to act independently because no cooperation was observed between red shiners when capturing Colorado pikeminnow larvae.

Logistic regression analysis (SAS 1993) was used to estimate the probability of capture as a function of predator TL, prey TL, predator $\mathrm{TL}^{2}$, prey $\mathrm{TL}^{2}$, and the predator-prey TL interaction (PPI). A general linear model was fit using the method of maximum likelihood, and Akaike's corrected information criterion (AIC ${ }_{c}$; Akaike 1981; Burnham and Anderson 1998) was used to identify a reduced model that best explained variation in probability of capture. Model selection suggested that the best predictors of probability of capture, $P$ (capture), were prey $\mathrm{TL}^{2}$ and the PPI term. The form of the size-dependent capture equation was

$$
\begin{aligned}
\operatorname{logit} P(\text { capture })= & -2.26-0.0136(\text { prey TL })^{2} \\
& +0.0036(\mathrm{PPI})
\end{aligned}
$$

which can be transformed to probability of capture as follows:

$$
P(\text { capture })=e^{\operatorname{logit} P(\text { capture })} /\left(1+e^{\operatorname{logit} P[\text { capture }]}\right) .
$$

Attack rate.-Direct estimation of the rate of encounter and the rate of attack given an encounter requires extensive data about the behavior and physical abilities of the species of interest (Gerritsen and Strickler 1977; Bailey and Batty 1983; Fuiman and Gamble 1989). As an alternative to gathering that information, we used a methodology that combined the probabilities of encounter and attack into a single parameter that estimated the number of attacks per day on individual larvae (hereafter called attack rate) as a function of predator length, Colorado pikeminnow larva length, and environmental conditions that included presence or absence of both alternative prey and turbidity. Data for estimating attack rate were obtained from outdoor mesocosm experiments. Mesocosms were intended to mimic characteristics of backwaters typically occupied by Colorado pikeminnow larvae in Green River nursery habitat (Tyus and Haines 1991). Plastic wading pools (diameter, $1.5 \mathrm{~m}$ ) were positioned on a sloping surface so that water depth in each mesocosm ranged from 0 to $25 \mathrm{~cm}$. Pools were filled with well water and substrate was $1-2 \mathrm{~cm}$ of washed sand. Mesocosms had a water surface area of $1.48 \mathrm{~m}^{2}$ and contained about $225 \mathrm{~L}$ of water. A factorial design similar to that described for estimating probability of capture was used, except that the $38-\mathrm{mm}$ TL predator group was not included because observations showed that capture rate was very low. A total of 69 individual mesocosm trials were completed over all size-groups of larvae (mean prey $\mathrm{TL}=9.8-20.1 \mathrm{~mm}$ ) and conditions; we tested effects of turbidity and alternative prey with several prey size-classes. In each trial, three red shiners from each size-group were introduced into pools and allowed to acclimate overnight. Colorado pikeminnow larvae were floated in plastic bags in mesocosms and allowed to acclimate for approximately $30 \mathrm{~min}$ before being released at the start of trials. Standard trials were conducted under daylight conditions for $6 \mathrm{~h}$ using clear water and no alternative prey, conditions intended to maximize predation by red shiners. Additional trials were conducted using environmental conditions hypothesized to reduce predation by red shiners: turbid water, and presence of alternative prey (chironomid larvae). Mesocosm turbidity was manipulated by adding a suspension obtained from mixing unwashed sand and water until a Secchi depth of about $5 \mathrm{~cm}$ was achieved. Observations showed that water turbidity remained high for the duration of the trials. Chironomid larvae were used as alternative prey because they are known prey items of early life stages of Colorado pikeminnow in the wild (Muth and Snyder 1995). Preliminary studies showed that maximum consumption of chironomid larvae by red shiners over a 6-h period was about $10 \%$ of body mass. To avoid predator satiation, the total mass of prey provided (Colorado pikeminnow larvae or chironomids) never exceeded $10 \%$ of combined predator mass. Consequently, the number of pikeminnow larvae used in each trial varied as a function of predator mass and ranged from 227 for the smallest larvae to 15 for the largest. The number of chironomid larvae ranged from 25 to 100 , with an equal mass of Colorado pikeminnow larvae in each treatment. Water temperature during trials was usually $25-31^{\circ} \mathrm{C}$. At the conclusion of a trial, a standardized protocol was used to remove predators and remaining prey from pools. Five preliminary tests showed that the protocol recovered $100 \%$ of a known number of 10 mm-TL Colorado pikeminnow or chironomid larvae. 
The response variable measured for each mesocosm trial was number of larvae eaten. To estimate the number of attacks that occurred in a trial, the number of larvae eaten was divided by its respective sizedependent capture probability (equations 1 and 2; e.g., if 10 larvae were eaten and probability of capture was 0.25 , then, attacks $=10 / 0.25=40$ ). Total attacks was then divided by the number of predators (usually 3). A global general linear model was used to estimate an equation for number of attacks per trial per individual larva (distributed as Poisson, number of prey was used as an offset) as a function of predator $\mathrm{TL}$, prey $\mathrm{TL}$, predator $\mathrm{TL}^{2}$, prey $\mathrm{TL}^{2}$, predator feeding strategy, water clarity, alternative prey, and first-order interactions. Predator feeding strategy was included because preliminary observations suggested that groups of red shiners exhibited different levels of predation that were not related to their size. We assumed that the different behaviors represented the range of feeding strategies employed by groups of red shiners in the natural environment. A maximum likelihood model was fit, and model selection was by $\mathrm{AIC}_{c}$. Model selection suggested that the best predictors of attack rate were prey TL, predator feeding strategy, water clarity, and alternative prey. The form of the attack-rate equation was

$$
\begin{aligned}
y= & -4.75+0.147\left(x_{1}\right)+0.910\left(x_{2}\right)+1.157\left(x_{3}\right) \\
& -0.439\left(\mathrm{fs}_{1}\right)+0.1036\left(\mathrm{fs}_{2}\right)-4.45\left(\mathrm{fs}_{3}\right) \\
& -1.88\left(\mathrm{fs}_{4}\right)
\end{aligned}
$$

$y=\log _{e}$ (number of attacks on an individual larva in a mesocosm per $6 \mathrm{~h}$ per predator);

$x_{1}=$ prey $\mathrm{TL}(\mathrm{mm})$;

$x_{2}=1$ if water is clear, 0 if water is turbid;

$x_{3}=1$ if alternative prey is absent, 0 if present;

$\mathrm{fs}_{1}=1$ if simulating the feeding strategy of predator group 1 , else $=0$;

$\mathrm{fs}_{2}=1$ if simulating the feeding strategy of predator group 2, else $=0$;

$\mathrm{fs}_{3}=1$ if simulating the feeding strategy of predator group 3 , else $=0$;

$\mathrm{fs}_{4}=1$ if simulating the feeding strategy of predator group 4 , else $=0$.

Note that when all fs coefficients $=0$, the model simulates the feeding strategy of predator group 5 . Standard errors for coefficients are as follows: intercept $=0.557, x_{1}=0.0294, x_{2}=0.266, x_{3}=0.331, \mathrm{fs}_{1}=$ $0.272, \mathrm{fs}_{2}=0.239, \mathrm{fs}_{3}=1.224$, and $\mathrm{fs}_{4}=0.360$. A goodness-of-fit test did not detect significant lack of fit of the data to the model $(P=0.25)$. Model fit was further assessed by plotting deviance and chi-square residuals as functions of predictor variables and predicted values. No trends in residuals were observed.

\section{Field Studies}

Drift net samples.-Colorado pikeminnow larvae were sampled with drift nets at two locations in 1991 and 1992. The lower Yampa River site was located about $1 \mathrm{~km}$ upstream of the confluence of the Yampa and Green rivers. The second site was located in the Green River about $15 \mathrm{~km}$ upstream of Green River, Utah (Figure 2). Sampling started in mid to late June 4 6 weeks after peak spring discharge when daytime water temperature exceeded $16^{\circ} \mathrm{C}$ (Nesler et al. 1988; Tyus and Haines 1991; Bestgen et al. 1998). Sampling continued for 4-6 weeks after the first pikeminnow was captured and ended when no larvae were captured for 3-5 consecutive days (usually mid-August; Bestgen et al. 1998). Colorado pikeminnow larvae were sampled daily at dawn with conical drift nets $\left(0.15-\mathrm{m}^{2}\right.$ mouth diameter, 4-m long, 560- $\mu \mathrm{m}$ mesh) set near shore in water $30-40 \mathrm{~cm}$ deep. Three nets were set on each sampling occasion for up to $2 \mathrm{~h}$, but sampling stopped if debris load exceeded $3.8 \mathrm{~L} /$ sample. Flowmeters (General Oceanics, Miami, Florida, Model 2030) were suspended in each net mouth to continuously measure through-net water velocity during sampling periods. Additional diel and cross-channel sampling in 1992 in the Yampa River showed that daily nearshore samples collected at dawn adequately represented the spatial and temporal distributions of drift of Colorado pikeminnow in the Yampa River (Bestgen 1997; Bestgen et al. 1998). Therefore, dawn samples were the only ones used to describe patterns of reproduction and drift abundance of Colorado pikeminnow in the Green River system in this study. We were confident the sampling regime encompassed the Colorado pikeminnow reproductive season because there were few or no larvae captured the first several days of sampling, larvae were absent in collections before conclusion of sampling, and only a few autumn juveniles had estimated hatching dates earlier than drift-net sampling dates. Samples were fixed and preserved in $100 \%$ ethanol. A standardized protocol was used to remove fish from sample debris within $4 \mathrm{~h}$ of collection. Tests with five samples showed that the protocol recovered $100 \%$ of a known number of larvae.

Seine samples.-Two $20-\mathrm{km}$ reaches in the Green River representative of habitat for young-of-year Colorado pikeminnow were sampled in 1991 and 1992. One reach (middle Green River nursery area) was located 407-427 river kilometers (RK) upstream of the confluence of the Green and Colorado rivers. The other reach (lower Green River nursery area) was located 69-89 RK upstream of the confluence. 
Colorado pikeminnow larvae (age-0) and age-1 to juvenile fish (hereafter collectively called juveniles) were captured from backwaters during summer (late July to early August) and autumn (late September to early October). Colorado pikeminnow were taken with a seine $(4.6 \times 1.3 \mathrm{~m} ; 1.6-\mathrm{mm}$ mesh $)$, preserved in $100 \%$ solutions of ethanol, and retained for otolith analyses.

Specimen analysis.-Colorado pikeminnow larvae from drift-net collections ( $<20 \mathrm{~mm}$ TL, but $99 \%$ were $<10 \mathrm{~mm}$ TL) and fish captured in seine collections in summer (9.0-25.4-mm TL) and autumn (15.9-66.9$\mathrm{mm}$ TL) were measured to the nearest $0.1-\mathrm{mm}$ via an ocular micrometer or calipers. Ages were estimated by counting daily increments in the left sagitta (larvae) or lapillus (larvae and juveniles) and averaging two to four independent counts. Otoliths from all but 9 of 1,929 fish examined were readable. Hatching date for each fish was calculated by subtracting its estimated age (d) from its date of capture. Regression analysis showed that ages of Colorado pikeminnow reared in water with daily temperature fluctuations, such as occur in backwaters of the Green River, can be accurately estimated up to $165 \mathrm{~d}$ after hatching using this method (Bestgen and Bundy 1998).

Hatching date distributions.-Distributions of hatching dates were used to assign fish to one of three or four intra-annual cohorts. Cohorts were divided to represent early, middle, and late summer reproductive output, and there was often a distribution mode associated with each cohort. The number and distribution of larvae and juveniles in each cohort were compared to determine if observed and expected survival were similar. In this analysis, expected distributions represented larvae captured in drift-net samples. Observed distributions were autumn juveniles from the same cohorts. We expected that the relative proportion of autumn juveniles captured in seine samples (observed distributions) should be similar to the proportion of larvae in expected distributions in the absence of size-dependent mortality. To account for sample-size differences for larvae and juveniles, the expected number of juveniles in each cohort was estimated by calculating the proportion of larvae in each cohort and multiplying this value by the total number of juveniles in each autumn sample. A loglikelihood ratio test ( $G$-test; Sokal and Rohlf 1969) was used to compare observed and expected proportions of autumn juveniles in cohorts.

One factor that may bias the results of this analysis is that wild larvae may suffer differential mortality through the summer because of differences in hatching time, particularly if sources of mortality other than that from red shiner predation exist (e.g., birds, larger piscivores). This may be true because early hatched larvae are at large for longer periods and, therefore, may undergo higher mortality than larvae hatched later, even if they have outgrown susceptibility to red shiner predation. We evaluated the importance of this potential bias by imposing a constant mortality rate of $5 \%$ per day on larvae so that early hatched fish would suffer higher cumulative mortality through the summer than late hatched fish (Bestgen 1997). The 5\% per day mortality rate was selected because it resulted in a survival rate for a group of larvae over a 90-d period of less than $1 \%$, a level which seemed reasonable based on studies conducted on species with similar-sized larvae (Houde 1987). The results of that analysis suggested fewer fish from early hatched cohorts remained in autumn than in the absence of the mortality factor, but conclusions about the rank order of relative survival rates and the contribution of juvenile cohorts to annual recruitment were unchanged. Thus, our conclusions about the relative contribution of various cohorts of larvae to the population of juveniles surviving to autumn were probably not biased by the amount of time larvae were at large.

A survival index of cohorts within a year (observed proportion of juveniles in a cohort/expected proportion) were compared to evaluate the relative contributions of various cohorts of larvae to recruitment (Crecco and Savoy 1985). Survival index values of 1.0 indicated that juveniles from a cohort occurred in equal proportion to larvae, whereas greater values indicated relative survival greater than that expected and lesser values less than that expected.

Growth rates. - Growth rates $(\mathrm{mm} / \mathrm{d})$ of juvenile Colorado pikeminnow captured in backwaters of the Green River were calculated by subtracting $5.5 \mathrm{~mm}$ (mean TL at hatch; Bestgen and Williams 1994) from TL at capture and dividing by age (d), which was estimated from otoliths. The mean and distribution of growth rates of juveniles within a cohort were qualitatively compared between summer and autumn samples to evaluate whether size-selective mortality was occurring between the two sampling dates. Growth rates of Colorado pikeminnow juveniles in summer that averaged less than those of fish that survived to autumn would indicate that relatively small and slow-growing fish were being selectively removed.

\section{Components of the Individual-Based Simulation Model}

Number of attacks.-Equation (3) was used to estimate the number of predator attacks per day on individual larvae based on environmental conditions. For each larva on each day, equation (3) was solved using larva TL, water clarity condition, alternative prey condition, and one of the five feeding strategies 


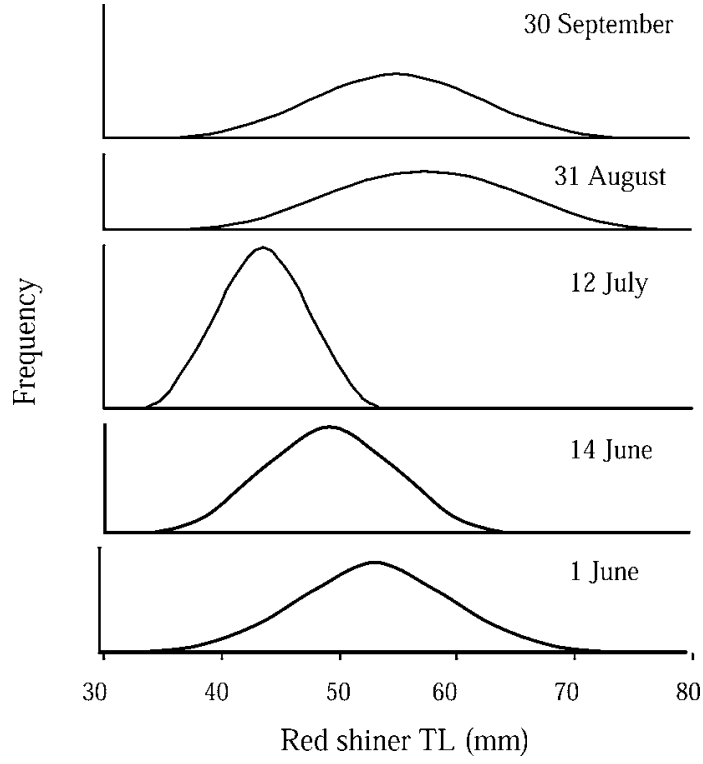

FIGURE 3.- Red shiner length frequency distributions used in the individual-based model. Distributions were based on field collections in the middle Green River, 1994. Daily distributions were estimated by linear interpolation of distribution means and standard deviations for simulation modeling.

selected at random. This daily attack rate was then multiplied by predator density (predators $/ \mathrm{m}^{2}$ ) to estimate mean number of total attacks. The actual number of attacks on the larva for that day was determined by drawing a value from a Poisson distribution with a mean equal to mean total attacks.

Red shiner density and size structure.-Estimates of red shiner densities and size distributions used in the IBM were based on 1994 field collections from the middle Green River, Utah (Haines and Tyus 1990; K. Bestgen, unpublished data). The size distribution and relative abundance of red shiners changed over time (Figure 3). In June, the population was predominated by relatively large age- 1 and age- 2 adults. From late June to late July, the size of fish in the red shiner population declined as old and reproductively spent fish died. Then, fish size increased as age-1 fish grew until water temperatures declined and red shiner growth rates slowed in autumn. Those size distributions and patterns of change over the summer were assumed representative for other reaches and years, based on summer size distributions of red shiners from Oklahoma and New Mexico, where large adults were common in early summer but uncommon in later summer (Farringer et al. 1979; Gido and Propst 1995; Gido et al. 1997). Limited sampling in Green River backwaters in July 1996 also showed a size shift similar to that observed in 1994, where large red shiner were relatively common in early July, but were rare later. During a simulation, red shiner size distributions were updated each day by linear interpolation between the mean and standard deviations of the data-based distributions. Each time a larva encountered a red shiner, predator total length was randomly drawn from the size distribution for that day. Adult red shiners regularly attain densities greater than five individuals/ $\mathrm{m}^{2}$ in Green River backwaters (Haines and Tyus 1990). Unless otherwise noted, we used a relatively conservative and seasonally constant density of three red shiner $/ \mathrm{m}^{2}$ in simulations.

Temperature-dependent growth.-To evaluate growth rate effects on predation, simulations were conducted using different Colorado pikeminnow baseline growth rates $\left(\mathrm{GR}_{\text {baseline }}\right)$. Those rates were adjusted for water temperature using the equation described by Bestgen (1996). Daily growth rate $\left(\mathrm{GR}_{\text {daily }}\right)$ was calculated using the equation

$$
\begin{aligned}
\mathrm{GR}_{\text {daily }}=\mathrm{GR}_{\text {baseline }}[ & (-0.279+0.0387 T \\
& \left.\left.-0.000637 T^{2}\right) / 0.283\right],
\end{aligned}
$$

where $T$ was mean daily water temperature $\left({ }^{\circ} \mathrm{C}\right)$. Each fish was assigned a baseline growth rate $(\mathrm{mm} / \mathrm{d})$ by randomly drawing a value from a normal distribution with a mean that was specified for each simulation and a coefficient of variation of $14.1 \%$ (Bestgen 1996). Mean baseline growth rates included in the analysis ranged from 0.2 to $0.6 \mathrm{~mm} / \mathrm{d}$, a range that represented growth rates of wild fish that survived to autumn. Baseline growth rate was adjusted as a function of water temperature via a proportion that increases or decreases growth rates when mean daily water temperature is higher or lower than $24^{\circ} \mathrm{C}$, respectively. The proportion was based on a temperature-dependent and ration-dependent growth equation (equation 5 in Bestgen 1996). The value 0.283 in equation (4) is the solution to the temperature-dependent and rationdependent equation at $24^{\circ} \mathrm{C}$ and high ration. In most simulations, we used a moderate mean baseline growth rate of $0.3 \mathrm{~mm} / \mathrm{d}$. The IBM simulations were conducted using two different summer temperature regimes (1 June to 30 September) from the Green River near Jensen, Utah (U. S. Geological Survey gauge 09261000), a relatively warm thermal regime during 1994 and a cooler regime in 1983 (Figure 4). We used main-channel water temperatures in simulations because they probably represent the average temperature present in backwaters on a daily basis. This is true because backwater temperatures are higher during the day but colder at night than the main channel (personal observations, KRB). Use of main-channel water 


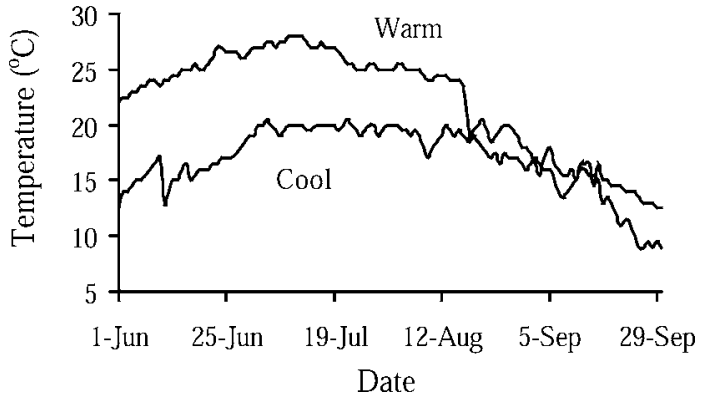

FIGURE 4.-Green River summer water temperature regimes during cool (1983) and warm (1994) years, as recorded near Jensen, Utah (U.S. Geological Survey gauge 09261000), and used in individual-based model simulations.

temperatures is further justified because development and growth of early life stages of Colorado pikeminnow do not vary between fluctuating or constant water temperature conditions, as long as a similar number of degree-days are available (Bestgen and Williams 1994; Bestgen 1996).

IBM simulations.-An individual-based modeling approach was selected because we suspected that individual differences in size and growth rates of larvae may have a strong influence on recruitment patterns (DeAngelis and Rose 1992; Rice et al. 1993). The IBM focused primarily on the interacting effects of life history variables and temperature on larval growth and survival and size-dependent predation by red shiners. Each simulation started with a cohort of 10,000 larvae arriving in nursery habitat. Each fish was assigned a hatching date (e.g., backwater arrival minus 8 d) so that simulation data could be compared with field data. Hatching date used in model simulations varied from 1 June to 1 August, a range consistent with dates of capture of newly hatched larvae in drift nets in the lower Green and Yampa rivers (Bestgen et al. 1998). Initially all larvae were $9.0 \mathrm{~mm}$ TL which is a typical size of Colorado pikeminnow larvae entering backwaters (Bestgen et al. 1998). Each larva was then assigned a baseline growth rate $(\mathrm{mm} / \mathrm{d})$ and the number of attacks it encountered during the day was calculated using equations (3) and (4). The estimated total number of attacks per predator in each 6-h mesocosm trial was multiplied as a function of pool area (1.48 to standardize to 1 predator $/ \mathrm{m}^{2}$ ) and time (14-h day/6-h trial $=2.33$, where a 14 -h day represented approximately the daylight period during summer in the Colorado River basin) to provide mean number of attacks per 14-h day on a larva. For each attack, a predator size was drawn from a predator size distribution, and the probability of capture was determined using equations (1) and (2). The probability that a larva would survive all attacks on a given day was the product of individual probabilities of surviving each attack on that day. Whether the larva survived the day was determined by drawing a number from a uniform distribution between 0 and 1 ; if the number was less than or equal to the larva's probability of survival for the day, then it survived. Probability of survival was set to 1 for larvae longer than $25 \mathrm{~mm}$ TL because laboratory observations showed that red shiners were not able to capture Colorado pikeminnow of that size. At the end of a day, length of each surviving larva was increased based on the larva's initial baseline growth rate and the daily water temperature via equation (4). This process was repeated for each larva; then the time step was incremented, and surviving larvae were exposed to predation the next day. Fish that survived to $25-\mathrm{mm}$ or 1 October were considered to have left the window of predation vulnerability and recruited to the age- 0 population in autumn. The duration of the window of predation vulnerability for Colorado pikeminnow is dependent on temperature and food abundance (Bestgen 1996; e.g., at maximum food ration a 9-mm Colorado pikeminnow would take $80 \mathrm{~d}$ to grow to $25 \mathrm{~mm}$ at $18^{\circ} \mathrm{C}$ but only $53 \mathrm{~d}$ at $26^{\circ} \mathrm{C}$ ). Each simulation was replicated three times using different random number seeds and results were averaged. Data describing numbers, size distributions, and growth rate distributions of survivors and mortalities were output for further analysis.

Comparison of model and field patterns.-Simulations were conducted with the IBM using hatching date distributions derived from larvae captured in drift nets in 1991 and 1992. This allowed us to compare recruitment patterns derived from IBM simulations to those obtained from analysis of otoliths in wild fish. The number of larvae input into the model on each day was scaled directly as a function of the number of larvae actually captured in drift nets multiplied by 10,000 (i.e., for each fish captured in a drift net, 10,000 were input to the model that day). On days when no larvae were captured within the known spawning season, a total of 10,000 larvae were added to the simulation day to account for inability of our sampling to detect low numbers of larvae. The magnitude of the scaling factor was chosen for convenience of conducting simulations and did not influence the outcome of the analysis because only relative survival indices were compared. Baseline growth rates used in simulations were based on otolith-estimated mean summer growth rates of wild Colorado pikeminnow (Bestgen 1997). Baseline growth rates were $0.41 \mathrm{~mm} / \mathrm{d}$ TL for fish in the middle Green River in 1991 and $0.43 \mathrm{~mm} / \mathrm{d}$ in 1992, and daily growth rates in the lower Green River 


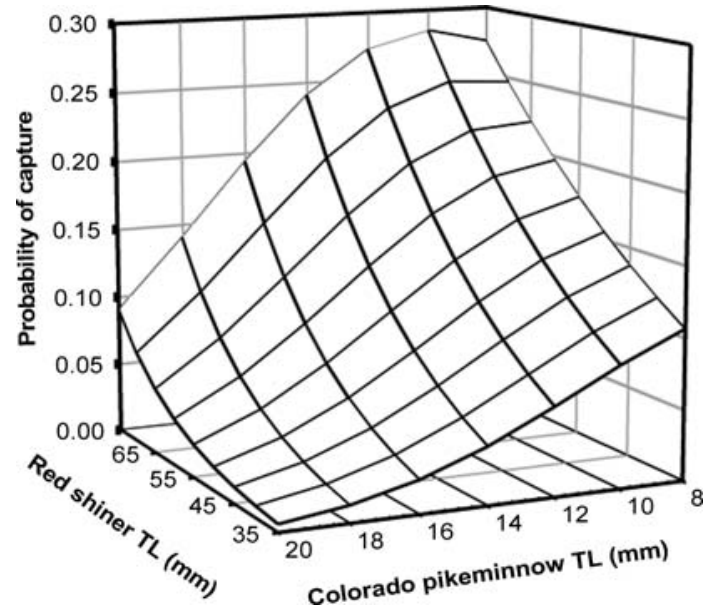

FIGURE 5.-Response surface of probability of capture of Colorado pikeminnow larvae by red shiner predators, as a function of prey total length ${ }^{2}\left(\mathrm{TL}^{2}\right)$ and predator-prey $\mathrm{TL}$ interaction.

were $0.44 \mathrm{~mm} / \mathrm{d}$ in 1991 and $0.31 \mathrm{~mm} / \mathrm{d}$ in 1992 . Red shiner size structure was that used for simulations described earlier. Mean daily water temperatures in simulations for corresponding periods were obtained from U.S. Geological Survey records from nursery habitat reaches of the middle (gauge 09261000) and lower Green River (gauge 09315000). Simulations concluded on dates that corresponded with timing of autumn field sample collections of Colorado pikeminnow (McAda et al. 1994), usually late September or early October.

\section{Results \\ Laboratory Experiments}

Probability of capture.-Predation experiments conducted in aquaria demonstrated that red shiners were moderately successful and persistent predators on Colorado pikeminnow larvae (Figure 5). Mean number of attacks by individual red shiners in a 20-min trial was 21 (0-72); inspection of data showed no relationship between number of attacks and red shiner length. Capture success was size-dependent for both predators and prey. Probability of capture ranged from near zero for small shiners attacking large larvae, to nearly 0.30 for large shiner attacking small larvae. Red shiners captured Colorado pikeminnow as large as 23mm TL.

Attack rate experiments.-Over all experimental conditions and prey sizes in the 6-h mesocosm experiments, red shiners captured an average of 7.9\% of the Colorado pikeminnow prey available. Attack rate was size-dependent, larger larvae being attacked more frequently than small ones. Solutions for equation (3) revealed that a $15-\mathrm{mm}$ larva was attacked about twice as often as a $10-\mathrm{mm}$ larva, and a $20-\mathrm{mm}$ larva was about 4 times as likely to get attacked as a $10-\mathrm{mm}$ larva. Relatively large and positive coefficients for turbidity and alternative prey in equation (3) demonstrated that presence of each factor significantly reduced attack and predation rate. Over all size-classes and in the absence of alternative prey, red shiners captured about $11.6 \%$ of pikeminnow prey in clear water but only $2.9 \%$ in turbid conditions. In clear water, red shiners captured about $11.6 \%$ of pikeminnow prey in the absence of alternative prey, but capture rates declined to $3.0 \%$ when alternative prey were present. Capture rate of pikeminnow prey when both turbidity and alternative prey were present in mesocosm trials was $1.0 \%$.

\section{Field Studies}

Distributions of hatching dates.-Hatching dates of larvae in the Green River in 1991 and 1992 were episodic, showing one or more distinct modes, which were often early in the reproductive season. The middle Green River group represented fish from the Yampa River spawning site that drifted downstream and occupied backwaters from near Jensen, Utah, downstream to Desolation Canyon. The lower Green River group represented fish from the Green River spawning site that drifted to backwaters downstream of Green River, Utah. In the middle and lower Green River in 1991 and in the middle Green River in 1992, larvae captured in drift nets began to hatch between 18 and 22 June (Figure 6), but in the lower Green River in 1992, they hatched as early as 8 June. In nearly all years and reaches, most hatching was completed by mid-July. The vast majority of larvae captured in drift nets were 8-10 mm TL and 6-8 d old, although larger and older larvae were occasionally captured later in the season. Larvae arrived in backwater nursery areas about $8-10 \mathrm{~d}$ after hatching, based on ages of larvae at upstream capture locations and downstream transport rates determined by stream flow rates.

Colorado pikeminnow were collected by seine sampling in late July or early August to follow their growth and survival in backwaters. Distributions of hatching dates of Colorado pikeminnow summer juveniles revealed that most fish captured were from either the first cohort of larvae hatched or the early portion of the second. Larvae with later hatching dates were not represented in the distributions, probably because the fish were not susceptible to the sampling gear used in backwaters or had not yet arrived.

Comparisons of distributions of hatching dates showed that large cohorts of Colorado pikeminnow 
Middle Green River 1991
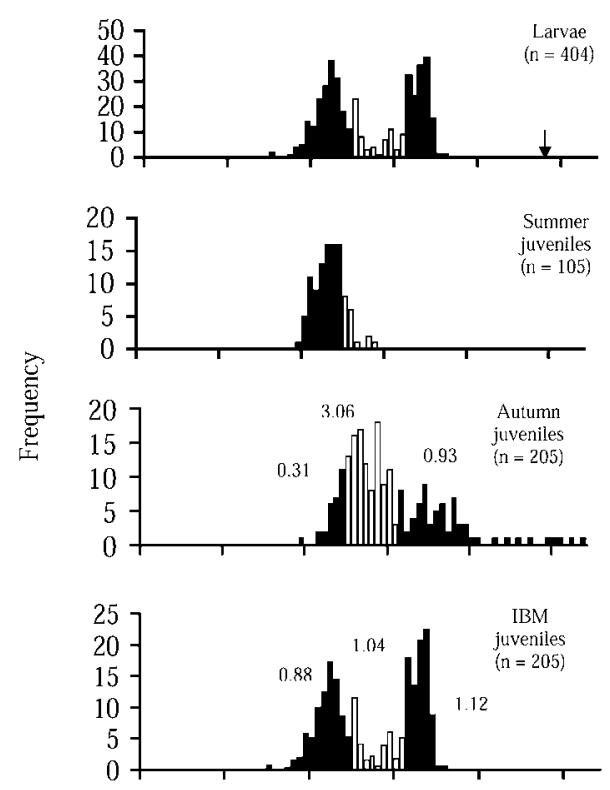

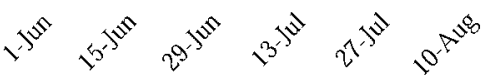

Middle Green River 1992

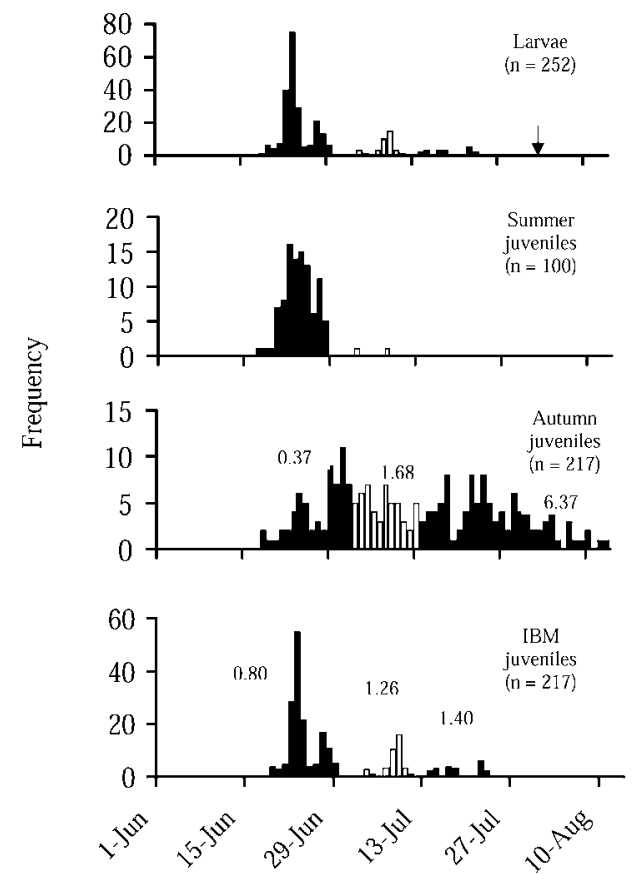

Lower Green River 1991
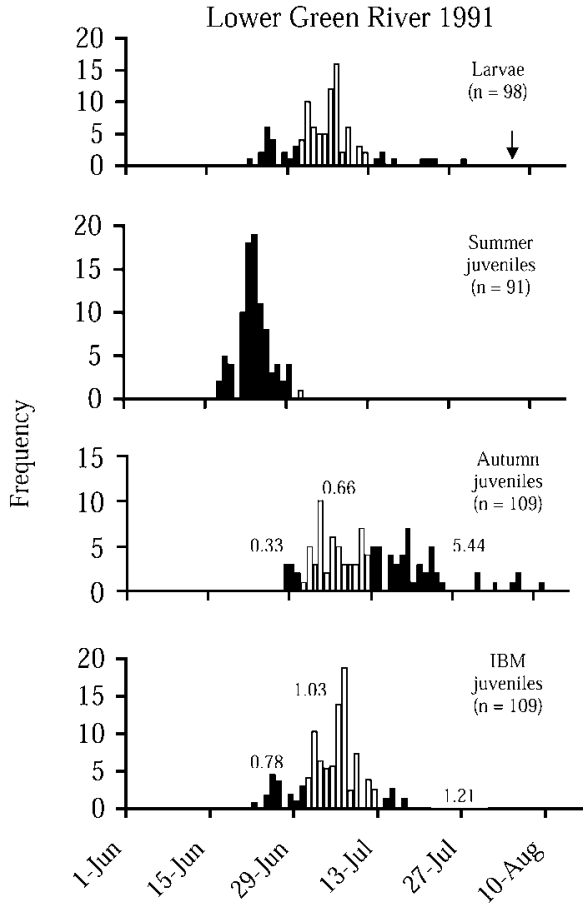

Lower Green River 1992
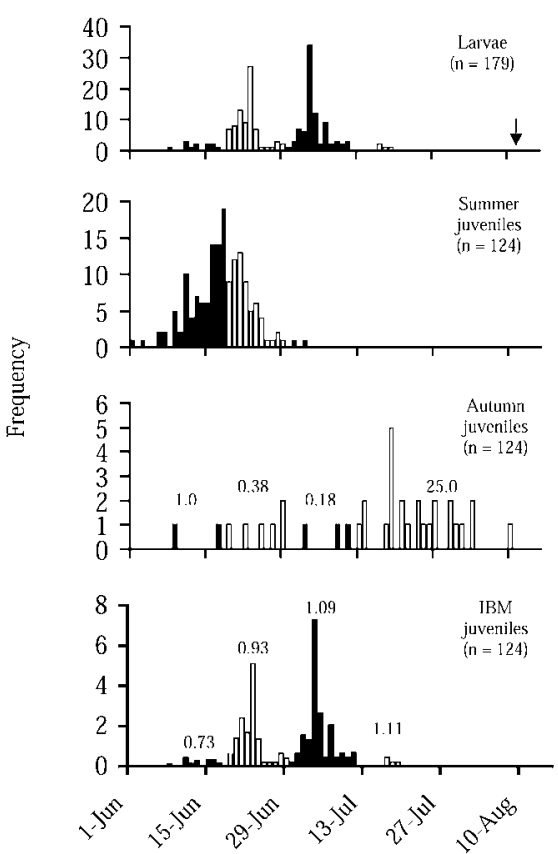

FiguRE 6.-Distributions of hatching dates of drift-net-captured Colorado pikeminnow larvae and seine-sampled juveniles captured in the middle and lower Green River in summer and autumn 1991 and 1992 compared with the distributions for IBM simulations using the hatching-date distributions of drift-net-captured larvae as input. First-cohort fish are represented by the leftmost set of black bars in each histogram, second-cohort fish by the white bars, and third-cohort fish by the rightmost black bars; the lower Green River in 1992 has a fourth cohort (rightmost white bars). Relative survival index values are given above each cohort for autumn juveniles captured in the field and juveniles in IBM simulations (see also Table 1). The arrow intersecting the larval hatching date axis represents the last date drift-net samples were collected. 
TABLE 1.-Recruitment patterns, mean growth (TL; mm), and sampling date for Colorado pikeminnow juveniles captured in summer and autumn from backwaters of the middle and lower Green River in 1991 and 1992. The $G$-test was used to compare the distributions of hatching dates of larvae captured in drift nets with those of juveniles in autumn captured with seines (Figure 6) to evaluate whether mortality varied with hatching dates. The relative survival index is the observed proportion of autumn juveniles in a cohort divided by the proportion expected from larval abundance; indices of 1.0 indicate that summer larvae occurred in the same proportion as autumn juveniles in that cohort, whereas indices greater or less than 1.0 indicate relative survival greater or less than that expected. The predominant cohort was the one that contributed most to recruitment in that reach and year. The predictions for recruitment and growth from individual-based-model (IBM) simulations are based on hatching date distributions for wild larvae.

\begin{tabular}{|c|c|c|c|c|c|c|c|}
\hline \multirow[b]{2}{*}{ Measured and predicted values } & \multicolumn{2}{|c|}{ Mean TL (range) } & \multicolumn{3}{|c|}{ Statistic } & \multirow{2}{*}{$\begin{array}{l}\text { Relative survival } \\
\text { indices of cohorts }\end{array}$} & \multirow{2}{*}{$\begin{array}{l}\text { Predominant } \\
\text { cohort }\end{array}$} \\
\hline & Summer & Autumn & $G$-value & df & $P$ & & \\
\hline \multicolumn{8}{|l|}{ Middle Green River, 1991} \\
\hline Measurement & $\begin{array}{c}17.3 \text { (14.4-20.8) } \\
\text { (1-2 Aug) }\end{array}$ & $\begin{array}{l}35.9 \text { (17.6-53.4) } \\
\quad(20 \mathrm{Sep})\end{array}$ & 160.7 & 2 & $<0.0001$ & $0.31,3.06,0.93$ & 2 nd of 3 \\
\hline IBM prediction & & $31.0(12.8-54.0)$ & & & & $0.88,1.04,1.12$ & 3 rd of 3 \\
\hline \multicolumn{8}{|l|}{ Lower Green River, 1991} \\
\hline Measurement & $\begin{array}{c}21.2 \text { (12.9-27.0) } \\
\text { (31 Jul) }\end{array}$ & $\begin{array}{l}39.2(22.0-65.0) \\
\quad(20 \mathrm{Sep})\end{array}$ & 107.8 & 2 & $<0.0001$ & $0.33,0.66,5.44$ & 3 rd of 3 \\
\hline IBM prediction & & $38.1(15.5-62.3)$ & & & & $0.78,1.03,1.22$ & 3 rd of 3 \\
\hline \multicolumn{8}{|l|}{ Middle Green River, 1992} \\
\hline Measurement & $\begin{array}{l}20.7(14.8-27.0) \\
\quad(29-31 \mathrm{Jul})\end{array}$ & $\begin{array}{l}43.2 \text { (21.5-66.9) } \\
\quad(25 \mathrm{Sep})\end{array}$ & 313.2 & 2 & $<0.0001$ & $0.37,1.68,6.73$ & 3 rd of 3 \\
\hline IBM prediction & & $41.4(16.9-62.3)$ & & & & $0.8,1.26,1.4$ & 3 rd of 3 \\
\hline \multicolumn{8}{|l|}{ Lower Green River, 1992} \\
\hline Measurement & $\begin{array}{l}14.7(9.0-29.9) \\
\quad(28-29 \mathrm{Jul})\end{array}$ & $\begin{array}{l}33.7(20.0-59.0) \\
\quad(19-20 \mathrm{Sep})\end{array}$ & 138.8 & 3 & $<0.0001$ & $1,0.38,0.18,25$ & 4 th of 4 \\
\hline IBM prediction & & $33.7(11.4-60.9)$ & & & & $0.73,0.93,1.09,1.11$ & 4th of 4 \\
\hline
\end{tabular}

${ }^{\text {a }}$ There were three cohorts for all locations and years except the lower Green River in 1992, for which there were four.

larvae do not necessarily produce large cohorts of autumn juveniles. In all cases, distributions of hatching dates for larvae and autumn juveniles were significantly different from each other (all $P$-values $<0.0001$, Table 1), in large part because larvae in the first cohort were much reduced or nearly absent from distributions for autumn juveniles. This was true even when early hatched cohorts of larvae were abundant and remained evident as summer juveniles. Second and third cohorts of autumn juveniles in the lower Green River, 1992, also had low relative survival indices. The bulk of autumn juveniles in each reach and year were typically larvae from the relatively late-hatching third or fourth cohorts, which had relative survival indices greater than 5. An exception was the middle Green River in 1991, when larvae from the intermediate second cohort had the highest relative survival. The very high relative survival index for cohort 4 in the lower Green River, 1992, was the result of poor survival of early hatched larvae and relatively high survival of the few larvae that hatched late. However, recruitment was very poor that year because neither the larvae from the two main modes detected by drift-net sampling nor the large early peak of summer juveniles were present in autumn.
Growth rates.-Within given cohorts, the mean growth rates of Colorado pikeminnow summer juveniles were lower than mean growth rates of autumn juveniles (Figure 7). This suggested that Colorado pikeminnow that survived to autumn represented the fastest growing subset of summer juveniles. For example, in the middle Green River in 1991, mean growth rates of autumn juveniles were greater in the first $(18 \%)$ and second (12\%) cohorts than were mean growth rates of summer juveniles in the same cohorts. Mean growth rates of autumn juveniles in the first to third cohorts from the lower Green River, 1992, were $56 \%$ higher than mean growth rates of summer juveniles, which suggested lower survival of fish with low growth rates. Mean growth of autumn juveniles in the third or fourth cohorts was the lowest of any cohort. Growth rate comparisons between summer and autumn juveniles for the third or fourth cohorts were not possible because summer juveniles were not available.

Thunderstorm-induced high-flow events in summer were associated with the slow growth of some Colorado pikeminnow in the lower Green River in both 1991 and 1992. Slow growth rates in 1991 occurred at a time coincident with a discharge increase from $76.4 \mathrm{~m}^{3}$ to $88.3 \mathrm{~m}^{3} / \mathrm{s}$ in the lower Green River, which began on 30 July and continued until about 12 


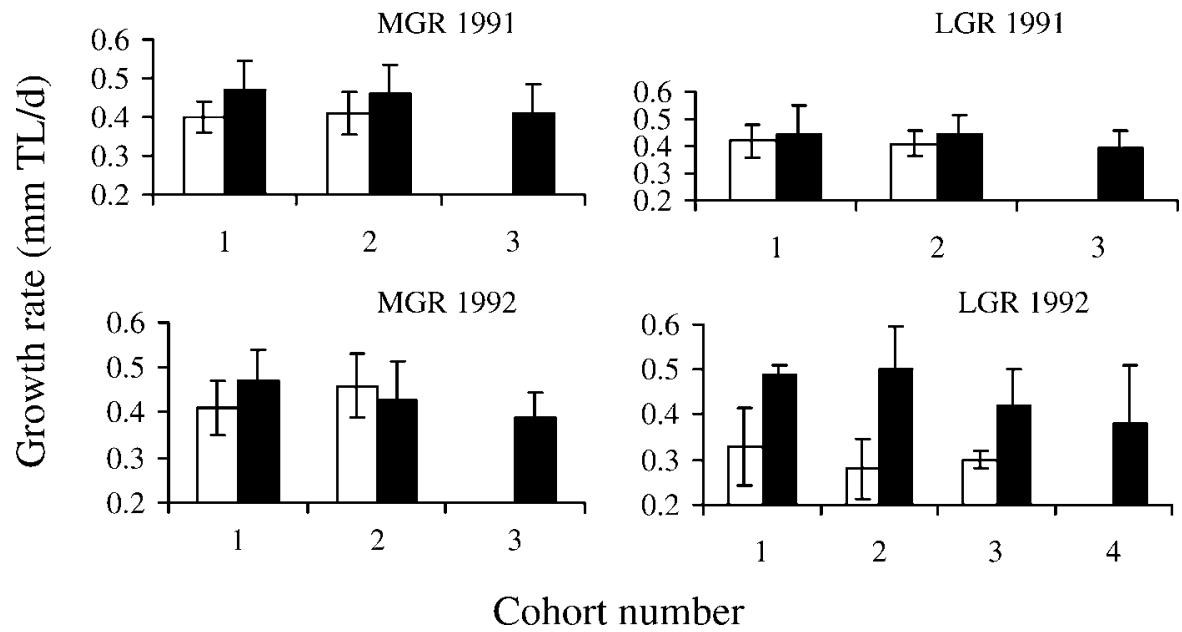

FIGURE 7.- Presumed effects of size-selective predation on mean growth rates (total length) of summer and autumn juvenile Colorado pikeminnow for each of three or four within-year cohorts, comparing summer (white bars) and autumn (black bars) in the middle (MGR) and lower Green River (LGR), Utah, in 1991 and 1992; whiskers = SDs. The single summer sample was collected before fish in the third cohort (fourth cohort in the case of the lower Green River in 1992) hatched, so there was no corresponding summer sample for those cohorts.

August. Mean growth rate was only $0.33 \mathrm{~mm} / \mathrm{d}$ TL ( $N$ $=7$ ) for fish that hatched in the third cohort during 31 July to 11 August, compared with growth rates of 0.43 $\mathrm{mm} / \mathrm{d}$ or greater for autumn juveniles hatched in the first or second cohorts. Summer juveniles in the lower Green River, 1992, which recruited poorly, were small upon capture and had the lowest growth rates observed in the study. Mean growth rate of autumn juveniles in the first, second, and third cohorts sampled in autumn was $50 \%$ or more higher than for summer juveniles in corresponding cohorts. Hatching dates for the first three cohorts preceded an extended period of higher discharge (53.5-100.8 $\mathrm{m}^{3} / \mathrm{s}$; 9 July until early August) from heavy and prolonged precipitation in the lower Green River basin. Most of the autumn juveniles from the fourth cohort that had relatively high survival hatched after discharge subsided.

\section{IBM Simulations}

We implemented the IBM to evaluate the relative effects of red shiner predation on the survival and mean TL of Colorado pikeminnow in cohorts at the end of the first growing season as a function of thermal regime, hatching date, larval growth rate, and predator density. The goal was to better understand interactions of red shiner predation and environmental factors on Colorado pikeminnow growth and recruitment and to determine whether patterns observed in simulations were consistent with those observed in the field. Most simulations were conducted with turbid water and alternative prey present because those conditions were typical for backwater nursery habitats in the Green River. Recall that those conditions produce the lowest attack rate, so predation results may be conservative compared with conditions where backwaters were clear or food was scarce. Unless otherwise specified, we used a moderate mean baseline growth rate of $0.3 \mathrm{~mm} /$ $\mathrm{d}$ for larvae, and a moderate red shiner density of 3 fish $/ \mathrm{m}^{2}$.

Effects of thermal regime and hatching date.-We ran scenarios with daily inputs of 500 larvae and hatching dates beginning on 1 June and ending on 1 August (6 red shiners $/ \mathrm{m}^{2}$ ) to examine the effect of hatching date and thermal regime on the survival of larvae. Red shiner predation was significant because survival of Colorado pikeminnow larvae was only 1.3$8.5 \%$ in the warm thermal regime (Figure $8 \mathrm{~A}$ ) and $0.8-$ $4.3 \%$ in the cool thermal regime. Survival was relatively low for larvae with early or late hatching dates compared with midseason hatching dates. Larvae that hatched early experienced rapid growth because backwater temperatures were relatively warm, but the larger and more efficient red shiner predators present during this time reduced larval survival. Larvae that arrived midseason in backwaters encountered the best conditions for survival because temperatures were warm and predators were relatively small. In these conditions, larvae experienced up to $30 \mathrm{~d}$ of rapid growth to sizes that were not susceptible to predation. In contrast, later-hatching larvae encountered smaller predators but experienced slower growth because of declining water temperatures. 

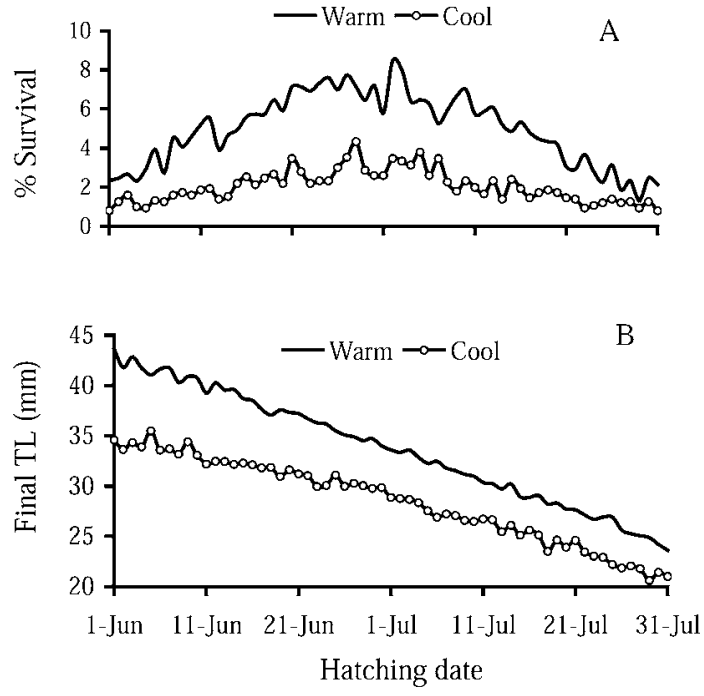

FIGURE 8.- Simulated effects of cool and warm thermal regimes and hatching date on (A) survival and (B) final total length (TL) of Colorado pikeminnow larvae that hatched from 1 June to 1 August in the Green River, Utah. Simulations ended 1 October, and predator density was 6 red shiners $/ \mathrm{m}^{2}$.

Colorado pikeminnow length at the end of the growing season was strongly affected by hatching date (Figure 8B). In both of the warm and cool thermal regimes, early hatching larvae reached almost twice the size of late hatching ones because they had more time to grow. Total lengths in simulations with the warm thermal regime were 12-26\% larger than those of fish with the cool thermal regime. Changes in length of Colorado pikeminnow over time showed that larvae hatched in June became invulnerable to red shiner predation by late July, whereas fish that hatched in late July were still small enough for large red shiners to consume at the end of the season.

Effect of predator density.-Predator density had a strong effect on the survival of larvae with a 1 July hatching date in both cool and warm thermal regimes. Survival in both cool and warm thermal regimes was over $50 \%$ at a red shiner density of $1 \mathrm{fish} / \mathrm{m}^{2}$ but $10 \%$ or less at a density of $6 \mathrm{fish} / \mathrm{m}^{2}$ (Figure 9A). The curvilinear response was due to the rate of change in the number of attacks and capture rates of larvae (from equation 3) as predator density increased. Water temperature had a strong effect; at the highest predator density about twice as many larvae survived the simulation period in warm water temperatures compared to cold.

Effect of growth rate of larvae.-In simulations, the mean growth rate of Colorado pikeminnow larvae had a large and positive effect on survival (Figure 9B).

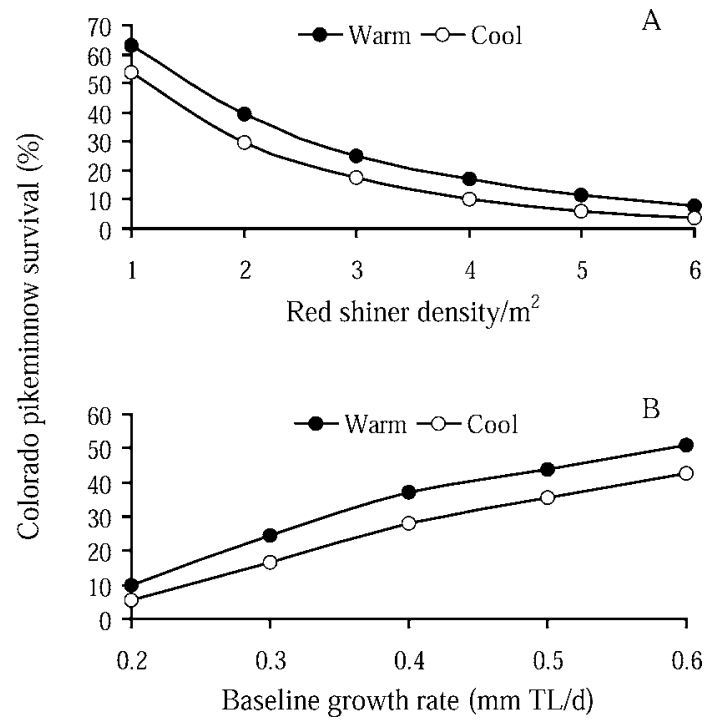

FIGURE 9.- Simulated effects of (A) red shiner predator density and (B) Colorado pikeminnow baseline growth rate on survival of age-0 cohorts of pikeminnow larvae in the Green River, Utah, using warm and cool thermal regimes. Colonization date was 1 July.

Those growth rates, 0.2 to $0.6 \mathrm{~mm} / \mathrm{d}$ TL, reflected the range we found for the wild age- 0 Colorado pikeminnow $(0.15-0.65-\mathrm{mm} / \mathrm{d}$ TL). Survival was relatively high $(40-50 \%)$ in cold and warm scenarios at the highest mean growth rate but less than $10 \%$ at the lowest mean growth rate. Water temperature had a substantial effect, especially at the lowest growth rate, where about twice as many larvae survived the simulated period in warm conditions.

Selection for fast growers.-In all simulations, growth rate varied among individual fish as it does in natural populations. Similar to growth rates observed in field studies, the simulated growth rates of Colorado pikeminnow that survived to the end of the growing season shifted to fish with faster growth rates compared with the initial distribution (Figure 10). This was because size-selective predation by red shiners tended to remove the smaller individuals with relatively low growth rates faster than fish with higher growth rates.

Comparison of model and field patterns.-Predictions of cohort relative survival from IBM simulations were similar to those observed for wild Colorado pikeminnow (Figure 6). Relative survival indices calculated for wild fish from the first annual cohort and for those simulated were 1 or less and were lower than relative survival indices in second, third, and fourth cohorts (Table 1). Similarly, relative survival indices were usually highest for fish in the last cohorts 


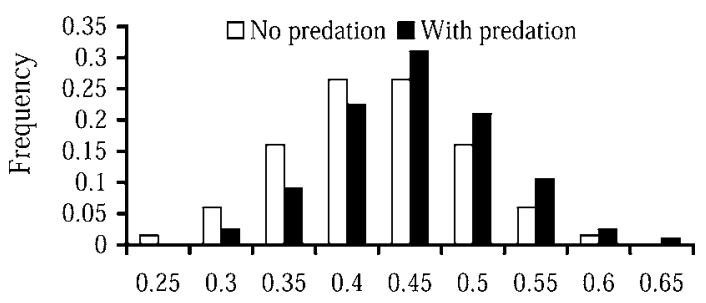

Growth rate $(\mathrm{mm} \mathrm{TL} / \mathrm{d})$

Figure 10.-Frequency distributions (means of five simulations) of growth rates of Colorado pikeminnow larvae in the Green River, Utah, with and without size-dependent predation by red shiners, as derived by an individual-based recruitment model. Individuals in both cohorts were assigned a growth rate by random draw from an initial distribution of growth rates that had a mean of $0.4 \mathrm{~mm} / \mathrm{d}(\mathrm{SD}=0.07)$.

in both simulations and the field, except for the middle Green River field data in 1991.

The mean TLs of Colorado pikeminnow from field data and IBM simulations were generally similar across river reaches and years (Table 1; Figure 11). The largest discrepancy was for the middle Green River, 1991, where mean length of Colorado pikeminnow juveniles in autumn was $4.9 \mathrm{~mm}$ greater than predicted from simulations. The IBM simulations did not predict the mode of late-hatching and relatively small Colorado pikeminnow observed in field samples, but simulated and field-collected fish had identical mean TL. Generally, length distributions were broader for wild fish than for simulations, probably a result of conservative estimates of the SD of growth rates used in simulations.

\section{Discussion}

We used experiments, field observations, and simulation modeling to produce a relatively comprehensive assessment of factors affecting recruitment of early life stages of Colorado pikeminnow. Small-scale laboratory experiments provided the basis for understanding a precise mechanism, size-dependent predation by red shiners on early life stages of Colorado pikeminnow and allowed estimation of effects of relevant field variables, such as turbidity and alternative prey, on predation. Field studies in the Green River provided scale-appropriate observations of the entire recruitment process for early life stages of Colorado pikeminnow, including observations of timing and intensity of spawning, effects of stochastic flow events, and patterns of intra-annual variation in recruitment and growth that were correlated with important but uncontrolled environmental variables. Congruence of recruitment hypotheses generated from laboratory
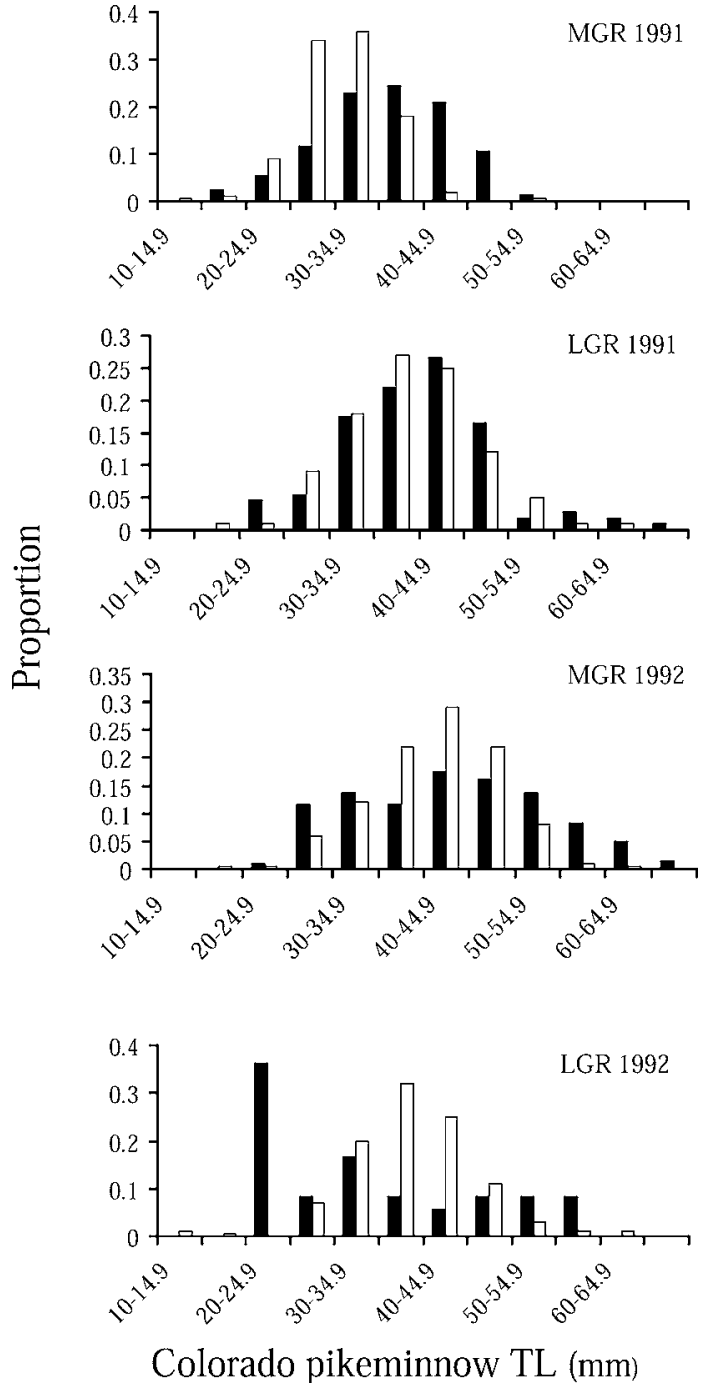

FIGURE 11.-Size-distributions of age-0 Colorado pikeminnow captured in autumn in the middle (MGR) and lower Green River (LGR), Utah, in 1991 and 1992 (black bars) compared with individual-based recruitment model simulations (white bars) that used drift-net captures of larvae as cohort inputs.

experiments and field data were evaluated with a model. The data-driven IBM we developed integrated numerous interacting factors, including seasonally varying water temperature and predator-size dynamics, and allowed evaluation of importance of those specific mechanisms to the recruitment process that would not be obvious from results of laboratory experiments or field observations alone. The IBM simulations produced predictions that were generally consistent with field observations, even though we only considered 
effects of a single predator, red shiners. Simulations also provide a means to evaluate potential outcomes of management scenarios (e.g., predator removal, variable temperature regimes) to enhance recruitment in wild populations before they are implemented. Integrated studies that include experiments, detailed field observations, and simulation modeling are well-suited to gain understanding of complex recruitment processes in fishes.

The body of information we gathered supports the thesis that the recruitment variation observed for early life stages of wild Colorado pikeminnow may be structured by interacting effects of physical factors and predation from nonnative fishes. Consistency of growth and recruitment patterns we observed in field studies combined with expectations from laboratory experiments and predation-driven IBM simulations led us to this conclusion. Predation by a novel and gapelimited predator, the small-bodied red shiner, may play a particularly important role, along with a host of other nonnative taxa that occur in backwaters of the Green River. Below we discuss components critical to this recruitment assessment for age-0 Colorado pikeminnow and their relevance to management.

\section{Laboratory Experiments}

The red shiner is not usually viewed as an important piscivore. However, experimental data showed that red shiners are effective at capturing Colorado pikeminnow larvae and the number of capture attempts by red shiners was relatively high. Large red shiners were generally the best predators, capturing and consuming pikeminnow that were up to one-third of their length (23-mm-TL pikeminnow captured by a $69-\mathrm{mm}-\mathrm{TL}$ red shiner), but a red shiner as small as $38-\mathrm{mm}$ TL consumed larvae. Because red shiners are gape-limited, growth rate of pikeminnow larvae determines their window of predation vulnerability.

Compared with laboratory experiments, mesocosm studies had a broader range of natural conditions, which included fluctuating water temperature, sand substrate, turbidity, and alternative prey. Even under these more natural and challenging conditions, mesocosm studies confirmed that red shiners were effective predators on Colorado pikeminnow larvae. Presence of turbidity and alternative prey greatly reduced attack and predation rate and made simulation results more representative of field conditions. An unexpected outcome of mesocosm experiments was that large larvae were attacked more frequently than small ones, even though probability of capture declined as pikeminnow size increased. Large larvae may provide more visual stimuli or have behavior or swimming speed differences that increase the likelihood of encountering predators. Another unexpected outcome was that different groups of red shiners demonstrated different levels of predation ability, which were independent of predator length. Additional study of differences in predatory behavior among red shiners may have theoretical and practical application.

The predation demonstrated by red shiners in experiments suggested that other small-bodied fishes in Green River backwaters may play important roles as predators on early life stages of fish, including Colorado pikeminnow. This was supported by Johnson and Dropkin (1992), who found that 15 relatively small-bodied fishes, including cyprinids, darters, and killifish that are not generally considered as piscivorous, consumed larval American shad Alosa sapidissima stocked in the Susquehanna River. Others have also documented predation by small-bodied fishes, including fathead minnow, which is an abundant nonnative resident of Green River backwaters (McGovern and Olney 1988; Dunsmoor 1995). Predation by small-bodied fishes, such as the widely introduced and abundant red shiner, deserves further recognition as a factor that may influence recruitment and recovery of rare native fishes. Expanding populations of smallmouth bass Micropterus dolomieu may exert an even greater predation pressure on a wide range of life stages of native fishes in Green River backwaters.

\section{Field Studies}

Intra-annual survival of cohorts of wild Colorado pikeminnow larvae in the field was highly variable, and the highest number of autumn juveniles did not originate from the largest cohorts of larvae. Distributions of hatching dates and growth rates of wild fish showed that the few early hatched larvae that survived to autumn were among the fastest growing individuals, suggesting that a strong size-selective mechanism was operating.

Early-hatched, wild Colorado pikeminnow larvae were also among the largest autumn juveniles because of their relatively longer growing season. Absence of autumn juveniles from large cohorts of early hatched larvae was probably not due to adverse physical conditions like cold water temperatures because water was warm when the first annual cohorts of larvae arrived in nursery habitats. It is possible that backwater food supply was scarce because the backwaters formed after high flows receded, which was just before colonization by Colorado pikeminnow larvae. This may be why growth was low and subsequent mortality was relatively high. Compared with early hatched individuals that grew relatively fast and were larger in autumn, later-hatching fish survived at higher rates but grew relatively slowly and were smaller in autumn. 
Based on simulation results, this scenario suggested that when large red shiners are present in early to midsummer, wild Colorado pikeminnow must grow quickly to survive to autumn. This hypothesis was supported because autumn juveniles averaged 12-73\% faster growth than summer juveniles. A potential explanation for this pattern is size-dependent predation mortality from a gape-limited predator. Under this hypothesis, slow-growing larvae should be susceptible to predators for a longer period of time than fastgrowing fish, so only the fastest-growing fish in a cohort survive (Houde 1987; Miller et al. 1988). Colorado pikeminnow hatched later in summer survived to autumn, even though they were slower growing, probably because large red shiners that caused differential mortality were not present.

Even though relatively small and slow-growing Colorado pikeminnow can survive to autumn, smallbodied juveniles may have relatively low overwinter survival. In a laboratory study, Thompson et al. (1991) found that both fed and starved Colorado pikeminnow that were relatively small (mean, 30 or $36 \mathrm{~mm} \mathrm{TL}$ ) had lower survival than larger fish $(44 \mathrm{~mm})$ over simulated winter conditions. In a Green River field study, Haines et al. (1998) found that small Colorado pikeminnow (mode, $28 \mathrm{~mm} \mathrm{TL}$ ) had only $6 \%$ overwinter survival during a high-flow winter period, whereas in a different year, when Colorado pikeminnow were larger $(>38$ $\mathrm{mm}$ ), they had higher overwinter survival (56-65\%), albeit winter flows were lower. Poor overwinter survival of small Colorado pikeminnow in the Green River places added importance on the few larger fish from early cohorts that survive, because those fish may have higher overwinter survival.

Intra-annual variation in survival of cohorts of larvae with different hatching dates has been observed for other freshwater fishes (Crecco and Savoy 1985; Rice et al. 1987; Limburg 1996; Cargnelli and Gross 1996; Mion et al. 1998; Garvey et al. 2002). Most of those studies invoked low temperatures or high flows as mechanisms for reduced survival of portions of the year-class. Poor survival of early spawned bloater Coregonus hoyi was thought a function of high predation rates on slow-growing larvae when water was relatively cold (Rice et al. 1987; Luecke et al. 1990), which similar to our study, suggested that bloater recruitment may be structured by interacting physical and biotic factors.

\section{IBM Simulations}

The IBM simulations confirmed patterns observed in field studies and provided support that predation interacting with environmental variables was a main mechanism structuring recruitment patterns. Simula- tions were also useful to explore "what if" scenarios such as the potential effect of reducing predator abundance or exploring effects of different thermal regimes on Colorado pikeminnow growth and recruitment.

Additional data are needed to make IBM simulations more representative of the processes in the Green River. For example, understanding seasonal size and density shifts of red shiners and other potentially predaceous fishes would better reflect the predator assemblage in backwaters. Information on the potentially important effects of discharge level and flow fluctuations on food availability and fish growth would also be useful, particularly if IBM simulations were linked to bioenergetics modeling (Burke and Rice 2002). This is important because discharge fluctuations, such as those produced by releases from hydroelectric dams or natural flow increases, reduce the abundance of nearshore chironomid assemblages (Blinn et al. 1995), which are important in the diets of most young fishes in the Green River (Muth and Snyder 1995).

\section{Alternative Recruitment Hypotheses}

Starvation is another possible mechanism affecting recruitment of early life stages of Colorado pikeminnow in Green River backwaters, but we found no support for that hypothesis. Starvation is primarily a function of body size for fish larvae (Miller et al. 1988), and Colorado pikeminnow larvae are only of moderate size at hatching (5.5 mm TL). However, 87\% of laboratory-reared larvae starved for $15 \mathrm{~d}$ after they could eat ( $21 \mathrm{~d}$ posthatch) survived when offered food (Bestgen 1996). Further, survival predictions from Miller et al. (1988) for larvae that hatch at the same size as Colorado pikeminnow suggested that pikeminnow have higher than average resistance to starvation. Thus, high starvation resistance makes it unlikely that direct starvation mortality is an important mode of population regulation.

We did find evidence that intra-annual flow fluctuations affected the recruitment of cohorts of Colorado pikeminnow larvae, perhaps through interactions with predation. This was apparent in the lower Green River in 1991 and 1992, when increased discharge and very high turbidity from thunderstorm runoff were associated with reduced growth and recruitment of juvenile Colorado pikeminnow. At discharge levels above $80 \mathrm{~m}^{3} / \mathrm{s}$, which was in the range observed in 1992, much of the available backwater habitat was eliminated in that mostly canyon-constrained reach (Haines and Tyus 1990; K.R.B., personal observation) and habitat loss may have reduced foraging efficiency and Colorado pike- 
minnow food abundance. Growth reductions may have extended the time that Colorado pikeminnow were susceptible to predators and that flow-predation interaction may be a cause for low recruitment of fish hatched during that period.

Physical factors such as river flow are suspected of having a strong influence on the recruitment patterns of fishes in other systems as well (Crecco and Savoy 1985; Tyus and Haines 1991; Mion et al. 1998). For example, poor recruitment of American shad produced early in the year in the Connecticut and Hudson rivers was associated with high discharge, cold water temperature, and slow growth of larvae (Crecco and Savoy 1985; Limburg 1996), whereas higher survival of later hatched cohorts was correlated with lower flows, warmer water, and higher food abundance. Similarly, river-spawning walleyes Sander vitreus also showed high intra-annual recruitment variation driven mainly by negative effects of higher discharge and water turbidity (Mion et al. 1998). Very high and extended summer flows also negatively affected abundance of age-0 Colorado pikeminnow in backwaters of the Green River in 1983 and 1984 compared with other years in the period 1979-1988 (Tyus and Haines 1991).

\section{Management Applications}

Management strategies to reduce fish predator abundance in Green River backwaters may enhance recruitment of early life stages of rare native fishes, including Colorado pikeminnow and endangered razorback suckers Xyrauchen texanus (Bestgen 1990; Tyus and Saunders 2000). Bundy and Bestgen (unpublished report) were able to temporarily reduce abundance of nonnative cyprinids by $90 \%$ or more with depletion sampling in backwaters of the Colorado River. Based on results presented here, similar reductions of red shiner and other potential predator fishes should have a positive recruitment effect on native fishes such as Colorado pikeminnow, if removals are timed with endangered fish reproduction. This may have occurred in the lower Green River, Utah, where intensive removal of abundant red shiners and other nonnative cyprinids in a short river reach was associated with persistence of relatively large early life stages of razorback suckers (Trammell et al. 2004). Less intensive removals over longer reaches in other years did not produce similar results. Because high discharge events also reduce abundance of nonnative fishes in backwaters (Haines and Tyus 1990; Stanford 1994; Gido et al. 1997), further exploration of the link between hydrology and nonnative fish abundance dynamics is warranted.

Simulations portrayed the complexities of recruit- ment dynamics of juvenile Colorado pikeminnow observed in the field and could be used to generate predictions of the relative effects of various management schemes on the recruitment and growth of Colorado pikeminnow. For example, Muth et al. (2000) recently proposed more natural flow patterns and water temperatures for Flaming Gorge Dam releases; this may enhance survival and growth of endangered fishes in the Green River system (Ward and Stanford 1995; Poff et al. 1997). The IBM offers one means to evaluate the relative benefits of flow and temperature modifications from Flaming Gorge Dam and effects of different annual hydrologic and temperature regimes on Colorado pikeminnow growth and recruitment. Establishing reliable links between survival and baseline growth rate of young Colorado pikeminnow relative to base flow level or flow fluctuations would make IBM predictions particularly useful. Effects of changes in temperature regimes could be simulated directly and would be most important in reaches close to the dam. Simulations could also predict size-structure of autumn juveniles, if seasonal production patterns of Colorado pikeminnow larvae were available. Managers could then better understand potential effects of late autumn and winter flow regimes from Flaming Gorge Dam that may influence growth or overwinter survival of Colorado pikeminnow, particularly if the autumn juveniles were small (Thompson et al. 1991; Haines et al. 1998). This may be particularly important in years when flows are relatively high and cold because Colorado pikeminnow reproduction is usually delayed under those circumstances (Nesler et al. 1988; Bestgen et al. 1998).

The abundance of juvenile Colorado pikeminnow has declined in the Green River since the mid-1990s (Muth et al. 2000), and that decline has been implicated as a main reason for the decline in abundance of adults since 2000 (Bestgen et al. 2005). As a result, additional research was initiated to understand factors associated with the recent decline of early life stages of Colorado pikeminnow, including the potential role of red shiners and other predators in backwaters. Increased survival of Colorado pikeminnow larvae, particularly those that hatch early in the reproductive season and grow to a relatively large size by autumn, should be investigated because those are the ones most likely to overwinter (Haines et al. 1998; Muth et al. 2000).

Investigations should consider habitat availability and quality, as well as the effects of nonnative fish predators, to minimize the effects of interacting biotic and abiotic factors that limit recruitment success of early life stages of endangered Colorado pikeminnow in the Green River Basin. 


\section{Acknowledgments}

Portions of the field studies were funded by the Recovery Implementation Program for Endangered Fish Species in the Upper Colorado River Basin, which is a joint effort of the U. S. Fish and Wildlife Service; U. S. Bureau of Reclamation; Western Area Power Administration; states of Colorado, Utah, and Wyoming; upper basin water users; environmental organizations; and the Colorado River Energy Distributors Association under a cooperative agreement (8-FC-4006460) with the Larval Fish Laboratory (LFL). Laboratory experiments and individual-based modeling efforts were funded by the National Park Service and the Midcontinent Ecological Sciences Center of the U. S. Geological Survey. Project administration was facilitated by L. Crist, C. Karas, R. Muth, N. Shropshire, C. Stalnaker, E. Wick, R. Williams, and S. Williamson. Laboratory and field assistance was provided by J. Bundy, G. Haines, B. Gutermuth, S. Meismer, T. Rolloff, H. Tillquist, M. Williams, and others. Unpublished data were provided by C. McAda and L. Lentsch. Reviews by D. Anderson, K. Fausch, B. Johnson, B. Kondratieff, R. Muth, and anonymous reviewers much improved this manuscript. This is LFL contribution 127.

\section{References}

Akaike, H. 1981. Likelihood of a model and information criteria. Journal of Econometrics 16:3-14.

Bailey, K. M., and R. S. Batty. 1983. A laboratory study of predation by Aurelia aurita on larval herring (Clupea harengus): experimental observations compared with model predictions. Marine Biology 72:295-301.

Bailey, K. M., and E. D. Houde. 1989. Predation on fish eggs and larvae of marine fishes and the recruitment problem. Advancements in Marine Biology 25:1-83.

Bestgen, K. R. 1990. Status review of the razorback sucker, Xyrauchen texanus. Colorado State University Larval Fish Laboratory, Final Report to the U.S. Bureau of Reclamation, Contribution 44, Salt Lake City, Utah.

Bestgen, K. R. 1996. Growth, survival, and starvation resistance of Colorado squawfish larvae. Environmental Biology of Fishes 46:197-209.

Bestgen, K. R. 1997. Interacting effects of physical and biological factors on recruitment of age-0 Colorado squawfish. Doctoral dissertation. Colorado State University, Fort Collins.

Bestgen, K. R., D. W. Beyers, G. B. Haines, and J. A. Rice. 1997. Recruitment models for Colorado squawfish: tools for evaluating relative importance of natural and managed processes. Colorado State University Larval Fish Laboratory, Final Report to U.S. National Park Service, Cooperative Parks Study Unit, and U.S. Geological Survey, Midcontinent Ecological Science Center, Contribution 95, Fort Collins, Colorado.

Bestgen, K. R., and J. Bundy. 1998. Environmental factors affect daily increment deposition and otolith growth in young Colorado squawfish. Transactions of the American Fisheries Society 127:105-117.

Bestgen, K. R., J. A. Hawkins, G. C. White, K. Chrisopherson, M. Hudson, M. Fuller, D. C. Kitcheyan, R. Brunson, P. Badame, G. B. Haines, J. Jackson, C. D. Walford, T. A. Sorensen, and T. Ben Williams. 2005. Population status of Colorado pikeminnow in the Green River Basin, Utah and Colorado. Colorado State University Larval Fish Laboratory, Final report to the Recovery Implementation Program for Endangered Fishes in the Upper Colorado River Basin, U.S. Fish and Wildlife Service, Denver, Colorado.

Bestgen, K. R., R. T. Muth, and M. A. Trammell. 1998. Downstream transport of Colorado squawfish larvae in the Green River drainage: temporal and spatial variation in abundance and relationships with juvenile recruitment. Colorado State University Larval Fish Laboratory, Final Report to the Recovery Implementation Program for Endangered Fishes in the Upper Colorado River Basin, U.S. Fish and Wildlife Service, Denver, Colorado.

Bestgen, K. R., and M. A. Williams. 1994. Effects of fluctuating and constant temperatures on early development and survival of Colorado squawfish. Transactions of the American Fisheries Society 123:574-579.

Blinn, D. W., J. P. Shannon, L. E. Stevens, and J. P. Carder. 1995. Consequences of fluctuating discharge for lotic communities. Journal of the North American Benthological Society 14:233-248.

Brandenburg, W. H., and K. B. Gido. 1999. Predation by nonnative fish on native fishes in the San Juan River, New Mexico and Utah. Southwestern Naturalist 44:392 394.

Bundy, J. M., and K. R. Bestgen. 2001. Confirmation of daily increment deposition in otoliths of young razorback suckers. Southwestern Naturalist 46:34-40.

Burke, B. J., and J. A. Rice. 2002. A linked foraging and bioenergetics model for southern flounder. Transactions of the American Fisheries Society 131:120-131.

Burnham, K. P., and D. R. Anderson. 1998. Model selection and inference: a practical information-theoretic approach. Springer-Verlag, New York.

Campana, S. E., and J. D. Neilson. 1985. Microstructure of fish otoliths. Canadian Journal of Fisheries and Aquatic Sciences 42:1014-1032.

Cargnelli, L. M., and M. R. Gross. 1996. The temporal dimension in fish recruitment: birthdate, body size, and size-dependent survival in a sunfish (bluegill: Lepomis macrochirus). Canadian Journal of Fisheries and Aquatic Sciences 53:360-367.

Carlson, C. A., and R. T. Muth. 1989. The Colorado River: lifeline of the American Southwest. Pages 220-239 in D. P. Dodge, editor. Proceedings of the International Large River Symposium. Canadian Special Publication of Fisheries and Aquatic Sciences 106, Ottawa.

Connell, J. H. 1961. The influence of interspecific competition and other factors on the distribution of the barnacle Chthamalus stellatus. Ecology 42:710-723.

Connell, J. H. 1985. The consequences of variation in initial settlement vs. post-settlement mortality in rocky intertidal communities. Journal of Experimental Marine Biology and Ecology 93:11-45.

Crecco, V. A., and T. F. Savoy. 1985. Effects of biotic and 
abiotic factors on growth and relative survival of young American shad (Alosa sapidissima) in the Connecticut River. Canadian Journal of Fisheries and Aquatic Sciences: 42:1640-1648.

DeAngelis, D. L., and K. A. Rose. 1992. Which individualbased approach is most appropriate for a given problem? Pages 67-87 in D. L. DeAngelis and L. J. Gross, editors. Individual-based models and approaches in ecology. Chapman and Hall, New York.

Doherty, P. J. 1991. Spatial and temporal patterns in recruitment. Pages 261-293 in P. F. Sale, editor. The ecology of fishes on coral reefs. Academic Press, San Diego, California.

Dunsmoor, L. K. 1996. Predation by planarian flatworms and fathead minnows on embryos and larvae of endangered suckers in Oregon. Pages 35-36 in G. P. Garrett and A. M. Sudyka, editors. Proceedings of the Desert Fishes Council 27. Paragon Printing, Austin, Texas.

Farringer, R. T., III., A. A. Echelle, and A. W. Knight. 1979. Reproductive cycle of the red shiner, Notropis lutrensis, in central Texas and south central Oklahoma. Transactions of the American Fisheries Society 108:271-276.

Fogarty, M. J., M. P. Sissenwine, and E. B. Cohen. 1991. Recruitment variability and the dynamics of exploited populations. Trends in Ecology and Evolution 6:241246.

Fuiman, L. A., and J. C. Gamble. 1989. Influence of experimental manipulations on predation of herring larvae by juvenile herring in large enclosures. Rapports et Procès-Verbaux des Réunions, Conseil International pour l'Exploration de la Mer 191:359-365.

Gaines, S., S. Brown, and J. Roughgarden. 1985. Spatial variation in larval concentrations as a cause of spatial variation in settlement for the barnacle, Balanus glandula. Oecologia 67:267-272.

Garvey, J. E., T. P. Herra, and W. C. Leggett. 2002. Protracted reproduction in sunfish: the temporal dimension in fish recruitment revisited. Ecological Applications 12:194205.

Gerritsen, J., and J. R. Strickler. 1977. Encounter probabilities and community structure in zooplankton: a mathematical model. Journal of the Fisheries Research Board of Canada 34:73-82.

Gido, K. B., and D. L. Propst. 1995. San Juan River secondary channel community studies permanent study sites. San Juan River Recovery Implementation Program, 1994 Annual Report, Albuquerque, New Mexico.

Gido, K. B., D. L. Propst, and M. Molles. 1997. Spatial and temporal variation of fish communities in secondary channels of the San Juan River, New Mexico, and Utah. Environmental Biology of Fishes 49:417-434.

Haines, G. B., and H. M. Tyus. 1990. Fish associations and environmental variables in age-0 Colorado squawfish habitats, Green River, Utah. Journal of Freshwater Ecology 5:427-435.

Haines, G. B., D. W. Beyers, and T. Modde. 1998. Estimation of winter survival, movement, and dispersal of young Colorado squawfish in the Green River, Utah. U.S. Fish and Wildlife Service, Final Report to Upper Colorado River Endangered Fish Recovery Program, Denver.

Hamman, R. L. 1981. Spawning and culture of Colorado squawfish in raceways. Progressive Fish-Culturist 43:173-177.

Hilborn, R., and C. J. Walters. 1992. Quantitative fisheries stock assessment. Chapman and Hall, New York.

Hjort, J. 1914. Fluctuations in the great fisheries of northern Europe viewed in the light of biological research. Rapports et Procès-Verbaux des Réunions, Conseil International pour l'Exploration de la Mer 2:1-228.

Holden, P. B. 1979. Ecology of riverine fishes in regulated stream systems with emphasis on the Colorado River. Pages 57-74 in J. V. Ward and J. A. Stanford, editors. The ecology of regulated streams. Plenum, New York.

Houde, E. D. 1987. Fish early life dynamics and recruitment variability. Pages 17-29 in R. D. Hoyt, editor. 10th Annual larval fish conference. American Fisheries Society, Symposium 2, Bethesda, Maryland.

Hunter, J. R. 1981. Feeding ecology and predation of marine fish larvae. Pages 33-77 in R. Lasker, editor. Marine fish larvae: morphology, ecology and relation to fisheries. University of Washington Press, Seattle.

Johnson, J. H., and D. S. Dropkin. 1992. Predation on recently released larval American shad in the Susquehanna River Basin. North American Journal of Fisheries Management 12:504-508.

Luecke, C., J. A. Rice, L. B. Crowder, S. F. Yeo, and F. P. Binkowski. 1990. Recruitment mechanisms of bloater in Lake Michigan: an analysis of the predatory gauntlet. Canadian Journal of Fisheries and Aquatic Sciences 47:524-532.

Limburg, K. E. 1996. Growth and migration of 0-year American shad (Alosa sapidissima) in the Hudson River estuary: otolith microstructural analysis. Canadian Journal of Fisheries and Aquatic Sciences 53:220-238.

Magnuson, J. J. 1991. Fish and fisheries ecology. Ecological Applications 1:13-26.

May, R. C. 1974. Larval mortality in marine fishes and the critical period concept. Pages 3-19 in J. H. S. Blaxter, editor. The early life history of fish. Springer-Verlag, Berlin.

McAda, C. W., J. W. Williams, J. S. Cranney, T. E. Chart, W. R. Elmblad, and T. P. Nesler. 1994. Interagency standardized monitoring program: summary of results, 1986-1992. U.S. Fish and Wildlife Service, Grand Junction, Colorado.

McGovern, J. C., and J. E. Olney. 1988. Potential predation by fish and invertebrates on early life history stages of striped bass in the Pamunkey River, Virginia. Transactions of the American Fisheries Society 117:152-161.

Methot, R. D. 1983. Seasonal variation in survival of larval northern anchovy, Engraulis mordax, estimated from the age distribution of juveniles. Fishery Bulletin 81:741750.

Miller, T. J., L. B. Crowder, and E. A. Marschall. 1988. Larval size and recruitment mechanisms in fishes: toward a conceptual framework. Canadian Journal of Fisheries and Aquatic Sciences 45:1657-1668.

Minckley, W. L., and J. E. Deacon, editors. 1991. Battle against extinction: native fish management in the American West. University of Arizona Press, Tucson.

Mion, J. B., R. A. Stein, and E. A. Marschall. 1998. River discharge drives survival of larval walleye. Ecological Applications 8:88-103. 
Muth, R. T., and D. E. Snyder. 1995. Diets of young Colorado squawfish and other small fish in backwaters of the Green River, Colorado and Utah. Great Basin Naturalist 55:95-104.

Muth, R. T., L. W. Crist, K. E. LaGory, J. W. Hayse, K. R. Bestgen, T. P. Ryan, J. K. Lyons, and R. A. Valdez. 2000. Flow and temperature recommendations for endangered fishes in the Green River downstream of Flaming Gorge Dam. U.S. Fish and Wildlife Service, Final Report FG-53 to the Upper Colorado River Endangered Fish Recovery Program, Denver.

Nesler, T. P., R. T. Muth, and A. F. Wasowicz. 1988. Evidence for baseline flow spikes as spawning cues for Colorado squawfish in the Yampa River, Colorado. Pages 68-79 in R. D. Hoyt, editor. 11th Annual larval fish conference. American Fisheries, Society Symposium 5, Bethesda, Maryland.

Osmundson, D. B., and K. P. Burnham. 1998. Status and trends of the endangered Colorado squawfish in the upper Colorado River. Transactions of the American Fisheries Society 127:957-970.

Pannella, G. 1971. Fish otoliths: daily growth layers and periodical patterns. Science 173:1124-1127.

Platania, S. P., K. R. Bestgen, M. A. Moretti, D. L. Propst, and J. E. Brooks. 1991. Status of Colorado squawfish and razorback sucker in the San Juan River, Colorado, New Mexico, and Utah. Southwestern Naturalist 36:147-150.

Poff, N. L., J. D. Allan, M. B. Bain, J. R. Karr, K. L. Prestegaard, B. D. Richter, R. E. Sparks, and J. C. Stromberg. 1997. The natural flow regime. BioScience 47:769-784.

Post, J. R., and A. B. Prankevicius. 1987. Size-selective mortality in young-of-the-year yellow perch (Perca flavescens): evidence from otolith microstructure. Canadian Journal of Fisheries and Aquatic Sciences 44:1840 1847.

Rice, J. A., L. B. Crowder, and M. E. Holey. 1987. Exploration of mechanisms regulating larval survival in Lake Michigan bloater: a recruitment analysis based on characteristics of individual larvae. Transactions of the American Fisheries Society 116:703-718.

Rice, J. A., T. J. Miller, K. A. Rose, L. B. Crowder, E. A Marschall, A. S. Trebitz, and D. L. DeAngelis. 1993. Growth rate variation and larval survival: inferences from an individual-based size-dependent predation model. Canadian Journal of Fisheries and Aquatic Sciences 50:133-142.

Roughgarden, J., S. Y. Iwasa, and C. Baxter. 1985. Demographic theory for an open marine population with space-limited recruitment. Ecology 66:54-67.

Roughgarden, J., S. Gaines, and H. Possingham. 1988. Recruitment dynamics in complex life cycles. Science 241:1460-1466.
Ruppert, J. B., R. T. Muth, and T. P. Nesler. 1993. Predation on fish larvae by adult red shiner, Yampa and Green rivers, Colorado. Southwestern Naturalist 38:397-399.

SAS. 1993. SAS technical report P-243, SAS/STAT software: the GENMOD procedure, release 6.09. SAS Institute, Inc., Cary, North Carolina.

Sokal, R. R., and F. J. Rohlf. 1969. Biometry. Freeman, San Francisco, California.

Stanford, J. A. 1994. Instream flows to assist recovery of endangered fishes of the upper Colorado River Basin. National Biological Survey Biological Report 24:1-47.

Stanford, J. A., J. V. Ward, W. J. Liss, C. A. Frizzell, R. N. Williams, J. A. Lichatowich, and C. C. Coutant. 1996. A general protocol for restoration of regulated rivers. Regulated Rivers Research \& Management 12:391-413.

Thorson, G. 1950. Reproduction and larval ecology of marine bottom invertebrates. Biological Review 25:1-45.

Thompson, J. M., E. P. Bergersen, C. A. Carlson, and L. R. Kaeding. 1991. The role of size, condition, and lipid content in the overwinter survival of age-0 Colorado squawfish. Transactions of the American Fisheries Society 120:346-353.

Trammell, M., S. Meismer, and D. Speas. 2004. Nonnative cyprinid removal in the lower Green and Colorado rivers, Utah. Upper Colorado River Endangered Fish Recovery Program, Final Report Project 87A, Denver.

Tyus, H. M. 1991. Ecology and management of Colorado squawfish. Pages 379-402 in W. L. Minckley and J. E. Deacon, editors Battle against extinction: native fish management in the American Southwest. University of Arizona Press, Tucson.

Tyus, H. M., and C. A. Karp. 1989. Habitat use and streamflow needs of rare and endangered fishes, Yampa River, Colorado. U.S. Fish and Wildlife Service Biological Report 89(14):1-27.

Tyus, H. M., and G. B. Haines. 1991. Distribution, habitat use, and growth of young Colorado squawfish in the Green River basin, Colorado and Utah. Transactions of the American Fisheries Society 120:79-89.

Tyus, H. M., and J. F. Saunders, III. 2000. Nonnative fish control and endangered fish recovery: lessons from the Colorado River. Fisheries 25(9):17-24.

Vanicek, C. D., and R. H. Kramer. 1969. Life history of the Colorado squawfish, Ptychocheilus lucius, and the Colorado chub, Gila robusta, in the Green river in Dinosaur National Monument 1964-1966. Transactions of the American Fisheries Society. 98:193-208.

Ward, J. V., and J. A. Stanford. 1995. Ecological connectivity in alluvial river ecosystems and its disruption by flow regulation. Regulated Rivers Research \& Management 11:105-119.

Welcomme, R. L. 1979. Fisheries ecology of floodplain rivers. Longman Group, New York. 